\section{THE CURRICULAR CANON IN NORTHERN THAILAND AND LAOS}

\section{Justin McDaniel*}

\begin{abstract}
Nissaya texts are idiosyncratic vernacular notes composed and used by Buddhist monks in Northern Thailand and Laos between the 16th and early 20th centuries. They evince a particular relationship of the authors with the classical (i.e., originally composed in Pali) scripture of Theravada Buddhism, as well as with their intended audience. They reflect certain understandings of the notions of authorship, textual authenticity, the possibility of translation, and homiletics. A comprehensive study reveals the early development of Buddhist curricula in the region and a detailed study pedagogical methods used in these texts affords us a way to describe the nature of Buddhist belief and practice with much greater precision. In this paper, I will demonstrate how the choice of source texts by nissaya translators and the commentarial services they employ reveal the contours of the pre-modern Northern Thai and Lao Buddhist curricula. By focusing on the development of curricula in the region before the middle of the 19th century, we can avoid the vagaries that come with the application of normative notions of the Theravada Buddhist canon to a region of diverse textual production and disparate intellectual expression.
\end{abstract}

* Assistant Professor of Philosophy and Southeast Asian Studies at Ohio University

Doctoral Candidate in the Department of Sanskrit and Indian Studies at Harvard University

\section{Introduction: What defines a canon?}

In 1983 Charles Keyes wrote:

"the evidence from monastery libraries in Laos and Thailand... reveals that what constitutes the Theravādin dhamma for people in these areas includes only a small portion of the total Tipitaka, some semi-canonical commentaries such as Buddhaghosa's Visuddhimagga, a large number of pseudo-jātaka and other pseudo-canonical works, histories of shrines and other sacred histories. Liturgical works, and popular commentaries. Moreover, for any particular temple-monastery in Thailand and Laos, the collection of texts available to the people in the associated community are not exactly the same as those found in another temple-monastery." 1

Steven Collins used this statement and the research that supported it to develop his notion of a "ritual canon." The "ritual canon[s]" are the collections of texts used at any particular monastery in the "actual ritual life in the area concerned." ${ }^{2}$ The term "practical canon," inspired by the work of Collins, was coined by Blackburne in her 1996 dissertation on the Saratthadipani from Sri Lanka and shows how the choice of texts to copy, translate, teach and preserve, both canonical and non-canonical, Pāli

${ }^{1}$ Collins (1990: 103).

${ }^{2}$ Ibid.: 104; David Carpenter comes to similar conclusions in his study of the canonicity of the Veda. He states that the Veda was "largely a symbolic source for the legitimation of current practice." The Vedas can only be understood as a canon for ritual action and "orthopraxy," not "orthodoxy." The Vedas as a canon and as texts, at least for its commentators like Bhartrihari, were inseparable from "the conditions of their practical employment." Carpenter (1992: 24-28). 
and vernacular, in any given Theravāda community actually must be seen as defining the particular canon of that region and time period. Derris, providing a succinct overview of this modern trend in Theravāda Studies, demonstrates that texts like the Jātakas, the Dhammapadaatthakathā, the Buddhavamsa and the Mangaladipani dominate Southeast Asian monastic libraries and archives.

Although, I do not want to simply create a canon that did not actually exist historically in Northern Thailand or Laos, I want to add to this current discussion in Theravāda Studies by emphasizing a new way to define a "canon" by focusing specifically on what Pāli texts were most commonly translated and were used in educational settings. ${ }^{3}$ I want to expand this idea of a practical canon by, first, looking at nissaya texts in Laos and Northern Thailand. Nissayas reveal their pedagogical purpose by the choice of the texts the authors chose to translate and comment upon, and the semantic content of the

\footnotetext{
${ }^{3}$ I thank Oskar von Hinüber for his personal comments on the danger of inventing canons that never existed historically or conceptually.

${ }^{4}$. See the Raicheunangseuporānlānnā ekasānmaigrofilm kong stāpanwijai chiengmai: 2521-2533 (Catalogue of Palm Leaf Texts on Microfilm at the Social Research Institute, Chiang Mai University: 1978-1990) (1991); Panchi Maigrofilm Kwang Luang Pabāng, Haw Papitapa Kwang Luang Pabāng, Hongsamut Haeng St Lao (Catalogues of Palm Leaf Texts on Microfilm from Luang Pabang, the Museum of Luang Pabang and from the National Library of Laos) (1999). Vernacular narratives and histories or translations and summaries of Pāli texts in the vernacular dominate these collections.
}

stories or the ritual instructions themselves. They also contain linguistic, material, and rhetorical features that serve pedagogical purposes. While certain canonical texts written in Pāli are found, and sometimes in large numbers and wide-spread across a region, the texts that were translated (i.e. nissayas) seemed to have formed a practical vernacular canon which dominated language instruction and were the subjects of sermons at rituals and other community events. The nissayas may be the evidence of, what I call, multiple "curricular canons." By focusing on what texts were actually taught, copied, and translated, we can break away from the scholarly tendency to study Pāli texts and not their, often quite different, vernacular translations. These curricular canons were not well-copied and beautifully illustrated for royalty and wealthy patrons. They did not remain unread and neglected in the royal libraries or large monastic libraries of Thailand and Laos, nor were they strictly collections of Pāli liturgical prayers, protective chants or blessings. Instead, they were individually fashioned lenses through which individual scholars read, translated and commented on Pāli texts in the vernacular and the individually forged megaphones by which they taught.

What Charles Keyes observed in 1983 can be confirmed today with even the most cursory inventory of the major monastic, royal and governmental manuscript libraries of Laos and Northern Thailand. ${ }^{4}$ Moreover, it was previously noted (although not extensively commented on) by Louis Finot in 1917, George Coedes from 1911 to 1935 and Pierre LaFont in $1982 .^{5}$

\footnotetext{
${ }^{5}$ See Finot (1917: 1-218); Coedes (1966); LaFont (1965: 429-545).
} 
Generally, the most popular texts were the anisamsas (blessings used in ritual and magical ceremonies), parittas (incantations for protection), chalongs (ceremonial instructions for both lay and religious ceremonies), aprocryphal jātakas (non-canonical birth-stories of the Buddha), kamavācās (ritual instructions and rules), local folktales, and tamnāns (relic, image and temple histories). ${ }^{6}$ The first three categories of texts have clear reasons for being the dominant texts preserved in the region due to their everyday usage in house, buffalo, temple and bodily blessings or for their usefulness in cases of revenge, fear, and lust (love potions and incantations are included here). The tamnāns are mostly, but certainly not exclusively, vernacular histories that have political, economic, social, aesthetic and educational reasons for being popular, which I have discussed in another article, but which is largely beyond the scope of this paper. I will discuss the aprocryphal jātakas, folktales and kamavacās below. What is important for my purposes is that untranslated Pāli canonical texts are often in the minority in these collections. ${ }^{7}$ Therefore, in 1990 Steven Collins wrote:

"we need empirical research into each individual case, not a simple deduction from the existence of the closed tripitaka produced by the Mahāvihāra. We need more research, for example, historical and ethnographic, on the actual possession and use of texts, in monastery libraries and elsewhere, and on the content of sermons and festival presentations to the laity, to establish more clearly than we currently can; just what role has been played by the works excluded in the canonical list." 8

Charles Hallisey surmises that modern scholars of Theravāda Buddhism have a "common assumption that a closed canon had a rigid and inviolable force." Therefore, there is often a distinction made between canonical and apocryphal texts that exists in the mind of the scholar, but not the members of individual Theravāda communities. Therefore, following Collins, he notes that :

"an awareness of the special problems which the Theraväda faced in transmitting a systematic, but complex doctrine abstracted from a large and diffuse literary tradition is important for understanding the continuing

\footnotetext{
${ }^{6}$ For paritta literature in Southeast Asia see Skilling (1992: 109-82); for tamnāns see my brief overview in the forthcoming "Transformative History: Nihon Ryōiki and Jinakālamālipakaranam," Journal of the International Association of Buddhist Studies and references cited at the end of this paper. ${ }^{7}$ For example, I recently made a trip to the rural temple in Baan Nawm Lam Jan of Savaanakhet Province in Southern Laos. In this temple's rather large collection of manuscripts I found only one canonical text in Pāli -the Dhammapada. Although a few of this temple's manuscripts had been removed for microfilming by the National Library of Laos, the catalogue of the temple's collection held by the library had very few canonical texts and very few in Pāli. It also may be noted that the Pāli Dhammapada held by the temple was not complete and clearly, by its placement in the closet (tū) and the dust on its cover had not been untied or read in years (probably since the National Library's survey in 1993, since the label had been tied to the binding cord and neither seemed as if they had been tampered with). Furthermore, the abbot, Luang Pū Pommā, was unaware that he had a Pāli Dhammapada manuscript in the collection, but did call many attention to the several manuscripts of Lao folktales. ${ }^{8}$ Collins (1990: 104)

${ }^{9}$ Hallisey (1990: 161).
} 
literary activities of Buddhists in Sri

Lanka and Southeast Asia. This

awareness above all allows us to acknowledge the conditions under

which new suttas...could have been composed and accepted in the

Theravāda; it is easy to see that the very idea of a closed canon might well have functioned more as a rhetorical marker than as a strictly closed list in contexts where the canon circulated and was known in parts rather than as a whole." 10

We will see below that the canon was not only transmitted, chanted and held in parts rather than as a whole in premodern Southeast Asia, but it was translated and taught in even smaller vernacular parts alongside numerous non-canonical narratives, ritual texts, blessings and grammatical treasties.

John Cort's study of the "canon-near" and "canon-far" of the Svemtāmbar Jaina Communities of Gujarat echoes Collins' and Hallisey's call for scholars to pay more attention to what type of collection they are referring to when they use the term "canon." Cort, following Folkert's separation of Jaina scripture into two types of canon ${ }^{11}$ - Canon I

\footnotetext{
${ }^{10}$ Hallisey (1993: 105).

${ }^{11}$ The academic interest in defining the term canon has gained momentum in the last twenty-five years. K.R. Norman believes that a canon of religious texts can either be closed or open. By closed, he means that it consists of a fixed number of texts or utterances to which all additions would be considered the work of theologians, but not the work ofthe prophet or first promoter of the faith. Norman's study of the canonical tradition of Theravādan Buddhists shows that even though they claim to have a closed canon, many of the works contained therein are not
}

(canon-near) defined by "praxis" and the

and do not claim to be the words of the Buddha. Therefore, other parameters for canonicity, whether they be chronological, topical or other must be examined. (Norman, 1983: 140). Even the canon was considered closed before the common era, there are texts like the Milindapariha , Petakopadesa and the Nettipakarana which have been included in some Pāli canon collections and not in others. Origen used the term canon as an adjective with the phrase scriptuae canonicae, but the first nominative use was not until the fourth century. (Childs, 1979: 50). In the Jewish tradition, the definition of canon was simply "sacred writings" that would not "defile the hands." However, examining the philological evidence, we see that the canon meant simply a collection of texts written in a fixed historical period. These texts were decided as sacred by consensus and usually were determined as canonical by their status of being taught as the divinely inspired words of God. Marvin Pope, in his translation and historical study of the Song of Songs, elucidates the difficulty in defining canonical and non-canonical works. He gives detailed comparative philological evidence (by connecting to Egyptian love poems or extracting its secular topics) to show that it could be considered non-canonical in the basis of date, literary integrity, authorship, language style and topic. (Pope, 1977: 18, 29-33, 41-49, $66-67,72$ and 85 ). In scriptural traditions throughout the world and across history, canonicity is often defined, not necessarily arbitrarily, but definitely eclectically based on multiple and over-determined factors. Childs writes:

The term canon has both a historical and theological dimension. The formation of the canon of Hebrew Scriptures developed in a historical process, some lines of which can be accurately described by the historian. Semler was certainly right in contesting an exclusively theological definition of canon in which the element of development 
resultant contextualized understanding; Canon II (canon-far) defined by "authority" and "some intrinsic ontological value of the texts themselves." ${ }^{12}$ Cort employs the example of the Kalpa Sütra to illustrate his point. The Kalpa Sütra is a relative "minor"text in terms of its placement in the recognized critical edi-

was subsumed under the category of divine Providence or Heilsgeschichte of some sort. Conversely, the formation of the canon involved a process of theological reflection within Israel arising from the impact which certain writings continued to exert upon the community through their religious use. To seek to explain the historical process leading towards the formation of the canon solely through sociological, political, or economic forces prejudices the investigation from the start.(Childs. Introduction: 58)

This shows us that the canonical process is not on-going and limitless as maintained by James Saunders, but restrictive. However, the restrictions come under shifting rubrics of historical, literary, etc. Jonathan Z. Smith believes that the necessarily limiting function of the word canon that separates canonfrom commentary is a "radical and arbitrary reduction."(Smith, Jonathan Z. Imagining Religion: From Bablyon to Jonestown. Chicago: Univ. of Chicago Press, 1982: 43) He states that the only formal element that truly defines a canon is "closure."(Ibid.: 48) The reduction "represented by the notion of canon and the ingenuity represented by the rule-governed exegetical enterprise of applying canon to every dimension of human life is that most characteristic, persistent, and obsessive religious activity."(ibid.) That the making of the canon was a natural development of a religious people who seek to define their religion. tion of the Prakrit Jaina canon, but plays a primary role in the ritual life of Svemtāmbar Jains. Moreover, most Jains conflate the Sanskrit and vernacular commentaries with the Kalpa Sütra proper and consider the sculpted and illustrated representations and vernacular folktales based on these commentaries as part of the canonical sūtra. From this study Cort submits that the Jaina canon is more "fluid" than Western scholars have previously understood. The Theravāda canon of Southeast Asia is also more fluid. Prapod Assavavirulhakarn drew my attention to the fact that Thais use the term Tipitaka (i.e., the canon) to refer to all types of religious books, not simply the three baskets collected and arranged in Sri Lanka over 1,500 years ago. The monk who holds a printed copy of a vernacular commentary on a non-canonical text while he gives a sermon is considered to be reading the Phra tripitok (Tipitaka). Lao monks refer to nissayas as gampi tipidok (canonical scripture). One of the better selling books in the Mahāmakutarājawidyālai Bookstore (the largest religious bookstore in Bangkok) is titled the Phra tripitok chapap samrap brachāchon (The Tripitaka, (Common) People's Edition) which claims to be an abbreviated collection $(y \bar{o} k w \bar{a} m)$ of the 45-volume Mahāmakuțarājawidyālai Edition of the Pāli Tipitaka, but includes non-canonical material. ${ }^{13}$ A monastic student's textbook from Rong Phim Kānsāsanā, a

${ }^{12}$ Cort (1992: 175).

${ }^{13}$ Suchīp Buñ̃̃ānuphāp (1996). Studies of what constituted the Tipitaka in Burma are also rare. The Royal Orders of Burma report that on April 4th AD 1638 the king ordered the copying of "new sets" of the Tipitaka and assigned twenty learned monks as editors-in-chief,thirty as editors and ten 
popular press for religious textbooks in Bangkok, publishes a book titled Bramuan dhamma nai phra Tripitok (Dhammic Lessons in the Tipitaka) by Suddhipong Tontyāphisālasut, which draws from a mixture of canonical and non-canonical sources. ${ }^{14}$ There is no religious bookstore in the country of Laos which sells the Tipitaka (either the Pāli Text Society Edition or any of the severál Thai editions). Wat Ong Tēu, the central monastic university in Wiengjan, has a copy of the Burmese Script edition that is dusty and apparently unused. Their Thai edition remains unopened with some volumes still in plastic wrap. Pāli grammars and readers in Thailand generally contain passages from canoni

sub-editors to work at Maha Myal Muni Pagoda. He also had scribes and clerks work under them with thirty Shan guards to protect them. Later that month he ordered the production of 10,008 ivory plaques, 10,008 gold plaques, 10,008 silver plaques from the Ministry of the Interior and food from the Office of Graneries to support the monks and scribes. We have no idea though if these sets of the Tipitaka were similar to the PTS canon, what texts they included or left out and if these texts were similar to the long list of texts found on the mid-15th century inscription from Pagan, which is our best source for information on texts held and considered important in pre-colonial Burma. See Than Tun (1983: April, 1638); Luce and Tin Htway (1976).

${ }^{14}$ Suddhiphong Tontyāphisālasut (no date). ${ }^{15}$ Amnuay Sukhumānan (1989). I thank Peter Skilling for providing me with a copy of this source (as well as dozens of others over the past three years).

${ }^{16}$ Peter Skilling also gave me a quick description of the Chiang Mai Pițakamāla manuscript which is a long list (60 folios) of texts in the Tripitaka. This text, although as yet unedited and scrutinized, seems to change the order of many texts and expand the parameters of the Sri Lankan canon. cal and non-canonical sources without distinction.

There are some modern books like the Phra tripitok sangkhep (The Tipitaka Abridged) which contains only descriptions of canonical texts and monastic Pāli exams are separated into canonical and non-canonical sections (Although the most difficult exams and the ones that, if passed, give the highest respect are the non-canonical ones.). Moreover, Peter Skilling brought to my attention the Tamnān Hō Phrasamut (The History of the Monastic Library), which provides a detailed history of the copying and/or printing of various Thai editions of the Tipitaka from the mid-nineteenth century to the early twentieth century and which that generally follows the parameters of the Sri Lankan canon (Although many editions also include the major commentaries, expanding the canon from approximately 45 to 91 volumes.). Still, what is important is that the idea of the canon for most Southeast Asian Buddhists is simply wider than is commonly understood in the West or to largely Western educated Buddhist studies scholars at Asian Universities. ${ }^{15}$ Evidence from monastic holdings, translation practices, and, as we will see below, nissaya texts, leads us to believe that this fluid and more comprehensive sense of the term Tripitaka was even more prevalent before the introduction of the printing press (1830's) and foreign notions of what constituted the Theravāda canon. ${ }^{16}$

The common Thai and Lao notions of the canon and the research of Court, Collins and others show the difficulty of defining what constitutes a canon and the more insidious problem of allowing a "defined" canon to lead a scholar into assuming that the canon is universally 
read, understood, held, preserved and unaltered by the religious community that ideally adheres to it. In addition, Collins pointed out a general problem in the study of Theravāda Buddhism that I hope to address. To truly address this general problem, as he points out, we need targeted and specific research of certain regionally important texts. Therefore, the first part of this paper will look in detail at nissaya texts. I chose nissaya texts, at the suggestion of both Oskar von Hinuber and Charles Hallisey, because they are extremely common throughout manuscript collections in Northern Thailand and Laos and have never been studied by scholars locally or internationally. There is a serious lack of study of nissayas as a genre of Buddhist commentaries and early vernacular translations and more generally a total absence of previous studies that focus on the nature of Thai and Lao translations of Pāli texts, of which nissayas are the best example.

The nissaya genre is unique to Laos, Burma and Northern Thailand. ${ }^{17}$ Beginning as early as the 15th century, but becoming much more prevalent between 1720 and 1880 , monks began to translate Pāli texts in local vernacular languages using a variety of scripts. These nissaya (or "support") texts quickly became a popular medium to express doctrinal teachings, ritual practices, and daily monastic and lay obligations. Nissaya texts consist of Pāli words or phrases followed by vernacular translations, usually with numerous commentarial additions by the translator. Many nissaya texts were based on canonical Buddhist scriptures originally composed in Sri Lanka in Pali. However, in many cases the original Pāli text is not cited, or if cited, the Pâli phrase used in the nissaya cannot be located in the classical text. Furthermore, scholars in Laos and Northern Thailand often composed nissaya texts on non-canonical texts written in Pāli or on local Pāli narratives that cannot be traced back to an original Pāli version from Sri Lanka or India. These bilingual translations and/or commentaries vary from narratives, strict word commentaries, ritual instructions, and socio-ethical directives, and represent a singular creative endeavor in the emerging pre-modern states of Thailand and Laos. They also reveal a diverse and creative Buddhist scholarly atmosphere, which before now has been largely characterized as uniform and intellectually stagnant.

Nissayas reflect a stage of local Buddhist literature in which composing texts in Pāli was being largely replaced by vernacular translations, commentaries, summaries, ritual instructions and narratives. These vernacular texts either drew directly from the Pāli canon

\footnotetext{
${ }^{17}$ In Thailand and Laos there are several designations for translations: nissaya, nissai, nisai sab, khan, nisrai, and wohān. I am as of yet unsure as to why authors choose to use one term over another or why some scribes use two or three titles for their manuscript. For example, the Hā Sip Jāt Nissaya found at Wat Sung Men is entitled: "Wohān Hā Sip Chāt Nisrai Hā Sip Chāt." While I surmise that these titles are synonymous, I have yet to determine whether certain titles are used more in one region or at one time period more than another. In the Critical Study of the Northern Thai Version of the Panyasa Jātaka published by the Dept. of Thai at Chiang Mai University, it is mention that no one has found a manuscript of the Panyasa Jātaka in Pāli in Northern Thailand. However, they state that the only difference between nissayas and vohāras (wohān) is the amount of Pāli used in the text. This is oversimplified. Bhākwijābhāsa Thai (1978).
} 
and its commentaries or created new texts reflecting a creative engagement between local literary tropes and themes and Buddhist characters and Pāli literary structures. ${ }^{18}$ What is particularly interesting about nissayas is that their physical features, rhetorical style and choice of texts translated (object/ source texts) demonstrate that they were most likely employed as teaching aids for monks and novices who were learning to read/listen to and write both Pāli and the vernacular and guides to explaining Pāli words and passages for sermon

${ }^{18} \mathrm{McDaniel}(2002)$
${ }^{19} \mathrm{I}$ recently went to the two major monastic universities of Thailand and Laos to inquire about which texts they used to instruct Pāli. At Wat Ong Teu in Laos they do not use a standard Pāli grammar text, but instead, the instructor reads Pāli passages and translated them into Lao for his students. Translation is more at the level of memorization than detailed explanations of grammar or linguistic issues. The text he was using for the lesson on the day I interviewed him was an excerpt from the Dhammapada. At Wat Borworniwet (Mahāmakutarajāwidyalai) in Bangkok, instruction generally takes the form of memorization as well; however, there is a series of short paper-back Pāli grammars for novices. I am still unlcear on how they are incorporated in a Pāli lesson and need to investigate further. It may be noted that these grammars were hard to locate at the Wat Borworniwet bookstore and when I asked about what texts novices and monks used for Pāli study I was given a few bi-lingual liturgical texts with Pāli and Thai in two columns. These books are very prevalent at the bookstore and would be too numerous to list here. However the most common ones would certainly be: Phrakhrūrunathamrangsì. Monpïtī blāe samrap Phrabhiksusāmanen lāe Phutthasāsanikachon tua bai. Bangkok: Wat Arunrāchawararm, 2534 [1991] and the Suatmon chabub lu'ang. to both the lay and the ordained. The following two sections will provide evidence for this pedagogical thesis and discuss its relevance to the idea of the curricular canon in Northern Thailand and Laos.

What follows is a very brief overview of examples drawn from a wide variety of nissaya manuscripts collected in Northern Thailand and Laos. These are merely representative examples and are part of a more comprehensive study of nissaya texts in progress. The examples will suffice for the purposes of this paper and will show the need to determine what texts were most commonly used in educational contexts, thus helping to identify a curricular canon of a region or individual temple. Still, the larger pedagogical thesis which they support remains tentative and awaits examination of a wider collection of texts, a comparison of nissaya texts with other genres of vernacular commentaries and translation like vohāras, sābs, desanās and vernacular atțhakāthas and țīkās from the region, as well as a comparison of nissayas with the most common Pāli grammars used by monks in premodern Northern Thailand and Laos. ${ }^{19}$

\section{Object Texts}

Nissaya manuscripts generally range from one fascicle $(p h \bar{u} k)$ with approximately nine folios to 12 fascicles with over 250 folios. The choice of what texts the composers of the nissayas translated and commented on (object texts) is wide-ranging, but Pāli narratives from the Pañ ñasajātaka and Dhammapada-atthakathā and vernacular stories like the Madhurāsachamp $\bar{u}$ and ritual texts such as the sattaparitta and various kammavācās tend to dominate the different collections. A list of 
some of the most prevalent extant nissayas that I have had the opportunity to acquire and read are:

Channāburi Dhammapada Nissaya Mak Cet, Chiang Mai Kāthā Dhammapada Nissaya, Chiang Mai Sūtmon Nissaya, Chiang Mai Kit Nissaya, Chiang Mai Atthasālin $\vec{\imath}$ Nissaya mak bhaet, Lampāng Kammavācā Nissaya, Lü'ang Pabāng Kammavācā Nissaya, Lü'ang Pabāng Uposatha Khan Nissaya, Lü'ang Pabāng Xai Nōi Nissaya, Lü'ang Pabāng Saman Nissaya Mak Ton, Phrae Madhurāsachambu Nissaya, Phrae Hā Sip Chāt Nissaya, Wiangchan (Vientiene) Panchakanipāt Nissaya, Wiangchan Malai Bodhisat Nissaya, Wiangchan Phrakaeo Nissaya .

There are several other nissayas less common which I have not examined in any detail as of yet. Still, this list is a representative one and I am confident that it is large enough to allow us to make some generalities regarding the genre.

The choice of what texts and what words from a particular text to comment on and translate in nissaya form can tell us a great deal about the needs of the communities that composed them and what aspects of Buddhism were deemed more important and most necessary to teach, especially in the vernacular. Narratives and ritual texts are chanted or drawn from for instructions at ceremonies such as house-blessings, ordinations, the beginning and end of the rains retreats, etc. Therefore, they provide the perfect subject for sermons by a teacher for the benefit of his fellow monks, nuns and lay followers at these occasions. Translations of Pāli terms found in these texts is a common subject for sermons in present-day Thailand and Laos. The few dessanās (sermons) from the 17th to 19 th century that I have had the opportunity to examine employ a similar method. ${ }^{20}$ Nissayas, like dessanās, consist of lists of vernacular synonyms for Pāli terms or translations and illustrative explanations of the object text in question. I will offer a more detailed explanation of these methods below, but for now, what is important to note is that the choice of what canonical and noncanonical Pāli texts from Sri Lanka, as well as Pāli and vernacular texts from Thailand and Laos, to translate was in part an act in service of creating the local culture and provides insight into what texts were considered particularly efficacious for pedagogical purposes. Indeed, by the time the nissaya was composed, the Northern Thai and the Lao had centuries of familiarity and belief in Theravāda Buddhism. The nissayas may be seen as articulations of a particular understanding of the Theravāda in an attempt to make sense of a world in which the religion of the Buddha constituted the overarching and dominant system of belief and practice. The Lao and Northern Thai people used a foreign, translocal literary practice and plot structure to express their local practices, beliefs, values, social and historical concerns, and vernacular language. These texts are negotiations between the classical and vernacular, the translocal and the local. The nissayas incorporate local religious, cultural and linguistic elements into a non-native literary structure. Further research along these lines might lead us far in determining the

\footnotetext{
20 "There are a few manuscripts from Northern Thailand and Laos which have the titles 'desananissai' or 'voharanaissai'. There was clearly a link between these two genres. However, a full comparison between premodern desanas and nissayas would require a separate study."
} 
different modes of interaction between classical, translocal literature, and local, vernacular literature, among the various peoples of Southeast Asia. By looking closely at nissaya texts we can see the evolution of Pāli and vernacular, local Buddhist literature as processual and dynamic, reflecting strong ties to the past and engagement with the present.

Still, aside from these lofty reflections, there may be a very simple reason authors of the nissayas chose to translate the object texts they did. The narrative nissayas are simply entertaining stories. They may not systematically layout Buddhist ethics or doctrine or provide an accurate history of the Buddha's life, but they are funny, frightening, and memorable stories of magic, family crisis, wealth and love. Donald Swearer and Ranjani Obeyesekere have noted the prevalence of narratives as teaching tools in Theravāda Buddhist societies, and Bōsāenggām Wongtālā notes that stories from the Paññasajātaka collection and other stories are often requested by lay people to be told at religious ceremonies and family events (weddings,funerals, house-blessings, tonsure ceremonies, etc.). ${ }^{21}$ Therefore, monks have to be taught, as I was when I was a monk, to learn these stories and be able to chant them in Pāli. Excerpts from these stories are often the basis for sermons on these occasions. Could this have been the reason these narratives were translated as nissayas? It is wellknown that monks in Thailand are judged on their ability to relate a good story. ${ }^{22}$

Besides Jātaka style narratives, ritual texts are also common object texts for nissayas, and there are clear reasons why. The Kammavācā Nissaya explains the meaning of the Pāli chanted at one of the most common and public of Buddhist rituals - the ordination. The ordination ceremony is a time of great celebration and interaction between monks and lay people. Could the Kammavāca Nissaya (on the upasampada) have been used to train monks who would give a sermon to the lay people who were in attendance at the ordination? The Sattaparitta (Sutmon Nissaya) is a collection of mantras chanted for protective purposes at a number of Buddhist ceremonies. Therefore, would it not provide a logical subject for a sermon following the ceremony? These questions are basic and difficult to confirm without historical descriptions of sermons, of which there are few, and the ones we have are usually embedded in dramas, epic poems or narratives involving monks. However, a comprehensive study of these descriptions, as is so often the case in Theravāda studies, remains a desideratum.

Besides narratives and ritual texts, there are three nissaya manuscripts that I have read that are drawn from the Abhidhamma, seemingly for the purpose of teaching Pāli grammar (as we saw in a few examples given above), which was one of the main activities of any large monastic school. The Atțhakathāmātika Nissaya is a partial translation of the mátika of the

\footnotetext{
${ }^{21}$ Bōsāenggam Wongtālā (1987: 208); note also that vernacular epic poems which do not have any particular religious themes like the Thao Hung Thao Cheung and Xin Xai are also often chanted at Buddhist ceremonies in Laos. See Khongdeuan Bunyāwong (2000: introduction).

${ }^{22}$ Prijā Jāngkhwanyeun, Dhammavacana Wohān Thai, Bangkok: Chulalongkorn University Press, 2540 [1997]: introduction.
} 
Dhammasarigani that seems to also draw from explanations, in a non-systematic way, given in the mātikā section of the Atthas $\bar{a}$ linin. However, this is not simply a vernacular sub-commentary or a straightforward translation of the Atthasālini-atthayojanā written by Ñānkitti of Wat Panasārāma in Chiang Mai in the late 15th century, although it has certainly been influenced by the methods of grammatical instruction in the latter and helps the "reader" identify grammatical compounds in the Dhammasarigañ. ${ }^{23}$ While the Atțasālin $\bar{l}$ and the Mâtika (on the doublets or the triplets in the Dhammasangan $\bar{\imath}$ ) are not specifically grammatical texts, the nissaya uses these texts as a matrix on which grammatical lessons are based. These lessons were important to teach the audience how to identify terms (They are term-based grammatical lessons that provide lexicographies of related terms with alternate grammatical suffixes, as the syntax of sentences and long explanations of grammatical rules were usually not the concern of Southeast Asian authors). The identification of terms was important for chanting (to identify the first words of texts as pneumonic triggers) and for sermons that were based on the explanation and expansion of certain key Pāli terms. Furthermore, the mātikā of the Dhammasangani has played an important role in the history of Buddhism. In 1900, R.E. Iggleden noted that the $m \bar{a} t i k \bar{a}$ 's influence was "felt strongly throughout the whole of the Abhidhamma-Tipitaka. Not

${ }^{23}$ I have not been able to obtain a copy of A.K. Warder's (1961) PTS edition of the Mohavicchedani or a manuscript copy which may have also been a source text for this nissaya. only are the definitions and expansions of the classifications of this mātikā the material used in the states of the Dhammasangañ itself, but they form the basis on which a large proportion of subsequent discussion is built in the remaining books of the Pitaka." 24 He goes on to show that the terminology presented in the mātik $\bar{a}$ is fundamental to understanding how these terms, which generally refer to states of consciousness, are used throughout the whole Abhidhamma. The mātika is "used to isolate and establish the make-up of the khandhas... and [the terms in the mātikā] acts as a series of focal points." ${ }^{25}$ For these reasons we can see why the author of the nissaya would have wanted to emphasize the terms in the mātika through repetition, rather than translation, because they were technical terms his students would have had to be familiar with if any teaching based on material from the Abhidhamma was to be comprehended.

The Saccasankhepa Nissaya, another nissaya based on a grammatical text, is one of the few nissayas that generally follows its source text, but again it is incomplete and there seems to be no particular logic behind the author's decision to translate certain passages from its source text versus others, unless s/he was using the passages in question for the purpose of grammatical instruction unrelated to the source text's purported content. I have not as yet been able to identify the source text (if there is indeed only one) of the Nāma Nissaya from Chiang Mai; ' however, its purpose is clearly to provide a Pāli grammar lesson in Northern Thai. The text is badly broken and difficult to read, but, as far

\footnotetext{
${ }^{24} \operatorname{Iggeden}(1974: \mathrm{ix})$.

${ }^{25}$ Ibid.: xi-xii
} 
as I can tell, it is unrelated to the Nāmarūpasamāsa or the Nāmacāradipaka cited by Oskar von Hinüber in his Handbook of Pāli Literature. ${ }^{26}$ It is interesting to note that nissayas used for the instruction of Pāli grammar or translation of Pāli grammar texts are largely not found in Laos (Although a full investigation of grammatical manuscripts that may be nissaya-like, although not containing the word in their title, might reveal otherwise.).

The choice of what texts to translate and comment on in the vernacular was, according to the latest manuscript inventories, in no way standardized across the region or even from one temple to the next. While narratives and ritual texts tend to be the most prevalent, there are occasionally nissayas on abbreviated Pāli verses from the Abhidhamma and the Vinayya. Moreover, two manuscripts with the same title copied around the same period are often completely different. For example, Dhammapada Nissaya manuscripts (the most prevalent by far) reflect the fragmented nature of the process of composing nissayas. One Dhammapada Nissaya (mak 7) manuscript from Chiang Mai does not seem to have any direct connection to another Dhammapada Nissaya (mak 7) manuscript from Lū'ang Pabāng. Furthermore, from an examination of different manuscript collections in the region there are sixteen sections of the Dhammapada Nissaya. Each section is called a "mak."27 Each mak is of different length, ranging from 12-34 leaves. These mak do not correspond to the Pali Dhammapada's 26 vaggas ( chapters) or 423 verses. Moreover, there is not one monastic library that constains all 16 . Each mak seems to have been composed

26. Von Hinüber (1996: 164-175). independent of the others by different local scholars at different times in different places. I have collected numerous maks, but not all 16 and not different "recensions" of an individual mak, except for one - mak 7. I am attempting to collect and translate as many as possible, but from my experience, I am quite sure many of these maks will be mislabeled, have numerous missing or severely damaged leaves or simply be lost. In addition, one manuscript can have several pecia. Regardless, I believe that any attempt to collect "all" of the maks, place them in sequential order, and translate them as one text would be misleading, as to how they were composed and collected in their original context. It would create a false sense of "completeness." 28 I am confident that these maks were not composed in order, by one author at one place, or ever bound together as one large manuscript. There is simply no evidence of this for this nissaya or for nissayas in general. Instead, they are translations of individual Pāli narratives and word commentaries of the Dhammapada-atthakatha from Sri Lanka. The Lū'ang Pabāng mak 7, for example, is a Lao translation of the 252nd verse and commentary of the Pali Dhammapada-atthakatha with numerous additions and running sub-commen-

\footnotetext{
${ }^{27}$ The best, although somewhat misleading, English equivalent for this term would be "quire" or a several bi-folios sewn together. For a good description of manuscript codicology in Southeast Asia see Schuyler (1908: 281-83); see also the National Library of Thailand's guide to manuscript materials and production (Bāeprīen nangsēu bhāsāborān. Bangkok: Hōsamut hāeng chāt, 2543 [1999]; and, their older Käntham Samutthai lae Kāntrīem Bāilān. Bangkok: Hōsamut hāeng chāt, 2530 [1988].

${ }^{28}$ I thank Charles Hallisey for enlightening conversations with me about this issue.
} 
tary or paraphrase. The Lampun mak 4 is a northern Thai translation of another story from the Dhammapadaatthakath $\bar{a}$. These vernacular narratives and word commentaries seemed to have circulated independently and were considered complete texts in and of themselves and never read as a "complete" (i.e., all 16 maks) text. I have only found 16 maks in different places, this in no way means that 16 was the total number of maks of the Dhammapada Nissaya in any of these regions. Finally, there is only one mak that mentions the name of the author of the manuscript, but the colophon does not indicate whether the monk was the copyist or the original translator and does not mention the date of the work. Determining authorship is often a problem in Southeast Asian manuscript studies. ${ }^{29}$

Unlike modern English translations of Pāli texts published by the Pāli Text Society, Nissayas were rarely (if ever) translated as "complete" Pāli texts. The sections of Pāli source texts that are translated are manipulated for pedagogical purposes. When the source text can be identified it is usually a summary of that source text that lifts out Pāli words or phrases and then translates them while leaving many words, phrases, sections, etc. untranslated. Furthermore, narratives are occasionally left incomplete, passages seemingly vital to the plot are missing, and certain characters are emphasized, while others go unmentioned. Atthakathāmātikā Nissaya, the Atthasālin̄̄ Nissaya, the Kamavāca

${ }^{29}$ Many of the manuscripts I have collected or plan to examine this coming year are from Wat Sung Men in Phrae Province, Northern Thailand. There is better evidence for composers of Pāli manuscripts at this temple than at temples in Laos or even in Chiang Mai.
See Hundius (1990: 35-36).

Nissaya, and the Dibbamon Nissaya, are all incomplete translations of Pāli source texts and parts of their commentaries and sub-commentaries( if available). The Sutmon Nissaya is a commentary on selected passages of the Thai Sattaparitta (Cet Tamnān), which is itself a non-canonical collection of paritta texts. There is apparently no extant Pāli source text for the Madhurāsachampū Nissaya, the Näma Nissaya, the Saman Nissaya, the Lokabhāsā Nissaya, and the Kit Nissaya.

The last point I will mention as regards to object texts is that the choice of what texts to translate and comment on in the vernacular was, according to the latest manuscript inventories, in no way standardized across the region or even from one temple to the next. While narratives and ritual texts tend to be the most prevalent, there are occasionally nissayas on abbreviated Pāli verses from the Abhidhamma and the Vināya. Moreover, two manuscripts with the same title copied around the same time period are often completely different.

\section{Rhetorical Style}

While reading numerous nissaya manuscripts slowly, I soon became aware of certain repetitive syntactical structures, which actually taught me how to read the text. There was gradual lexical replacement at strategic intervals in these structures that allowed me to memorize Pāli vocabulary and their vernacular glosses without a concerted effort, very much like children's songs which slowly add new words within familiar syntactical structures. Three examples may suffice to illustrate my point. First, a Kammavācā Nissaya from Lü'ang Pabāng (KNLP-1.f 6.3-f.7v.1) 
reads:

"Pucchi kō thām nā kō yang nan vaccanena dūai khām wā gandā kō $\bar{\imath}$ dang nee // nāk dūrā nāk āba âdha $r \bar{\imath}$ phrayādhi thang lāi evarūpa an $m \vec{\imath}$ sahāwa pān dang $n \bar{\imath} / /$ tāe thā $g u^{\prime} w \bar{a}$ pen düma pen bao pen nap () santi mì sālile nai kāyya nü'a ton te hāeng thān w $\bar{u}^{\prime}$ an seun nāgo rì nak sammanēn // papijānti $^{30}$ gaw papinān khān rap $\bar{a}$ chariyam sōeng phrā achān vaccanena dūai khām wā natthi bhante bhante khā wai phrā achān // ābādhā $\vec{r} \bar{l}$ phrayādhi thang lai evarūpa an $\bar{m} \vec{\imath}$ sabhāva bān dang $n \bar{\imath} / /$ gand $\bar{a}$ g $\bar{u}^{\prime} w \bar{a}$ pen tüm pen bao pen nap natthi gaw bim sarire nai kāyya $n \bar{u}^{\prime} a$ tōn [sic] ${ }^{\prime 31}$

There is a gloss of the Pāli word gandā. First the novice asks what gandā means and receives the answer in bold "it is a boil, it is something swollen, it is a nap ( ); namely, these things are in the body (sālile) in the body, (which is) the flesh of you (te) of you that spreads over (you). Notice that in this gloss of the Pali word gandā there are two additional Pali glosses of the words sālile (särire) and $t e$. Furthermore, between the question, what does gandā mean and the answer, it is a boil, etc. there is another phrase which reads " $\bar{a} \boldsymbol{b} \bar{a} d h \boldsymbol{a}$ (disease/ mistake) means diseases in general; namely, that have characteristics like

${ }^{30}$ Oskar von Hinüber believes this is more likely pațijānāti.

${ }^{31} \mathrm{I}$ have typed all Pāli words that are drawn from the nissaya texts in italics and bold throughout to clearly separate them from the vernacular words. If a vernacular word is a cognate of a Pāli word and it is clear from the script and the syntax that the word was read as if a vernacular word then it will not appear in bold face. When the edges of the ms. are broken (which is quite common) or the alphabetical ordering of the folios are missing I have numbered the folios instead of using the indigenous alphabetical system. this." This phrase is repeated again on the next line and then the definition for ganda is repeated again in an abbreviated form. Therefore, the reader reads the gloss of gandā twice as well as reading the gloss of $\bar{a} \boldsymbol{b} \bar{a} d h a$ twice. What is interesting is that $\bar{a} \boldsymbol{b} \bar{a} d h \boldsymbol{a}$ had already been glossed in the manuscript several times before. Although not adding anything to the gloss of gandā, the gloss of $\bar{a} \boldsymbol{b} \bar{a} d h \boldsymbol{a}$ reminds the reader of the gloss of $\bar{a} \boldsymbol{b} \bar{a} d \boldsymbol{h} \boldsymbol{a}$ (which this entire section of the manuscript is about), while adding a gloss of a new Pāli word, gandā, which is a type of $\bar{a} \boldsymbol{b} \bar{a} d \boldsymbol{h} \boldsymbol{a}$. Moreover, when the glosses of both gandā and $\bar{a} \boldsymbol{b} \bar{a} d \boldsymbol{h} \boldsymbol{a}$ are repeated alternate spellings of sälile, sahāva, pān, and tūma are used sārire,

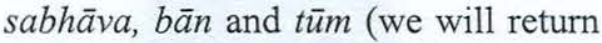
to the issue of orthography and phonetic spelling below). Finally, inserted within these glosses are glosses of common Pāli words like te and evarūpa and sārire, that had already been glossed several times before, and are simply reinforced here. We will return to this issue of reinforcement below.

The second example comes from a Dhammapada Nissaya (mak 7) from Channābuli (f.khāi.3-f.khām.v.1). This example reflects another type of repetitive glossing. On these three and one half leaves alone, although not limited to these leaves, the Pāli words meṇ̣̂a and/or setthi are mentioned 47 times. Mendaka is the name of one of the characters in this narrative and setthi is a treasurer or a wealthy person. Almost every time Mendaka is mentioned, he is called a setthi. While this in itself is not surprising, what is interesting is how many times mendaka is mentioned and the fact that his name is glossed in Lao nearly every time he is mentioned. For example, although mendaka had been 
introduced and re-introduced dozens of times in the story on folio khāo.4-5 we find:

"tasmim cā samaye nai kāla mü'a nan mendakagahapatti $\vec{r}$ mendaka setthi $m \bar{\imath}$ bun sompān an prasōet kwā kon thang lai hā kon an mì bun māk hai katam yang srī sampatti pen sețthi( ) phü pen kon an $\bar{u} a i$ nai wiang thi nan läe pañca dūai thang lai hā kon an mì puṇna māk nak meṇdakonāma ku' ton meṇ̣aka sețthi phü nu'ng [sic]"

"and at that time at that time when mendaka the householder who is known as mendaka the Wealthy One, the one who has excellent and important merit in greater amounts than all five others who also have ample amounts of merit, (he) obtained the (position) of a wealthy person; namely, a person who is important within that city among the five people who have great amounts of merit. His is known as mendaka, that is Meṇdaka the Wealthy One."

This is very repetitive and by reading or listening to line after line of glosses embedded in the narrative, the reader/ audience would surely not forget the name Mendaka or the fact that he was a wealthy person/treasurer. The repetition of phrases and words at frequent intervals allows the audience and scribe to memorize certain important words like aham, nāma, satthā, buddha, setțhi, dhamma, etc., as well as remember the main characters of the text. Any other reader (listener) or scribe (I was both, since I read, translated into English, and transliterated each manuscript into modern Thai or modern Lao.) would be able to remember numerous Pāli words, many specific to the story in question, and relate the main themes and characters of the story without reference to the text.
In the ninth and tenth folios of the Sutmon Nissaya from Chiang Mai, the terms mangala (auspicious) and uttamam are translated five times in exactly the same way. The passage reads "mangala pen manigala uttamam an udom ying nak" ("marigala is auspiciousness, uttamam(means) ultimate"). After reading or hearing this definition five times within two leaves, one surely would not forget it. marigala in Pāli is spelled the same way in Pāli and Northern Thai, but is pronounced differently (mon-kon) ${ }^{32}$ and since these manuscripts were most likely were written by a scribe listening to a teacher rather than copied from a written text (a point that will be discussed below), the difference would have been obvious. The Northern Thai word udom is phonetically and semantically cognate to uttamam. I use the term "ultimate"

${ }^{32}$ For more information on how script and pronunciation relate in Northern Thai see Hundius (1990: esp. 101, 127-139). Depending on how the ligature is written and the status of the final consonant in Northern Thai or Lao, two words spelt in identical ways can be pronounced differently. These differences can often be emphasized when reading a text out loud, but would be difficult to discern if read silently without the aid of a teacher familiar with the phonetic paramenters of both Pāli/Sanskrit and Northern Thai/Lao. While modern Thai script retains the spellings of words that are derived from Pâli/Sanskrit even though their vocalization does not follow their spelling, the Lao government have changed the Lao script three times in the past century. These changes have effectively dropped all letters from the alphabet which exist for the purpose of transliterating Pāli and Sanskrit. So, whereas the Thai alphabet has three different letters for the palatal, lingual and dental sibilants, in order to be able to write the three sibilants in Sanskrit. The Lao alphabet has dropped all but the dental 
to translate uttamam versus other possible definitions like "great," "north" or "important" because it takes into consideration the words that follow it ying nak (literally "great and heavy"), because when they follow a noun they make it superlative. Therefore, the repetitive definition teaches that mangala is cognate with Northern Thai (mon-kon), that uttamam and udom are cognate, even if spelt differently. The definition also employs alliteration.

One of the most excessive cases of repetition is found in the AtțakathāmātikaNissaya from Chiang Mai. Here the nissaya translates the $m \bar{a} t i k \bar{a}$, or "table of contents", of the Dhammasangani (the first book of the Abhidhamma). ${ }^{33}$ Now Why it would

sibilant where the Thai alphabet has two letters for the retroflexed and non-retroflexed "l" in Pāli, Lao has dropped to just one, since there is no phonetic equivalent to a retroflexed "l" in spoken Lao, etc. One of the most notable characteristics of epigraphy in Southeast Asia is the unusually large number of scripts employed to write both classi$\mathrm{cal}$ and vernacular languages. In the numerous Buddhist kingdoms that occupied what is now Thailand and Laos between the $13^{\text {th }}$ and $18^{\text {th }}$ centuries there often seems to be no rigid one-to-one correspondence between certain scripts and certain languages. Moreover, multiple scripts remained actively employed in every region up until the $17^{\text {th }}$ and $18^{\text {th }}$ centuries, even though certain languages fell out of usage. Strangely, there has been no serious attention paid to the question of why so many scripts were used and why a scribe would choose one script over another. I addressed this problem as it relates to scripts used on inscriptions at the $1999 \mathrm{Na}$ tional Conference of the American Oriental Society in Portland, Oregon. seem strange to devote an entire nissaya to translate the table of contents of one book of the Abhidhamma, there is a long tradition of composing commentaries and sub-commentaries and grammatical treatises on the $m \bar{a} t i k \bar{a}$ (see section I.C.). This nissaya continues that tradition, but instead of explaining the contents of the table, it uses the words in the mātika as a matrix for a Pāli grammatical lesson in the vernacular. For example, the first three folios (six lines per folio) are dedicated to explaining methods for reading compounds involving the compound vipāk $\bar{a}$ dhamma $\bar{a}$ found in the third verse of the $m \bar{a} t i k \bar{a}$. The first verse is barely mentioned and there is no mention of the second verse, but the third verse found itself the subject of a lengthy and repetitive translation/commentary. A section of it reads:

"vipāka iti mak wā ni adhivacana pen kō arupadhamma () nāmadhamma thang lāi... saddo reu sapda $\bar{a}^{34}$ vipāka dhammādhammā iti dang ni attho atthassavācano bōk yang atthavipākadhammadhammānāti

\footnotetext{
${ }^{33}$ Again I thank Oskar von Hinuber for pointing out that Frauwallner is a better edition of this text than Rhys Davids and that "table of contents" really obscures the meaning of the term; however, I was unable to obtain a copy of this edition before submission. The mātikā is a list of terms useful for memorizing a text.
}

\footnotetext{
${ }^{34} \mathrm{Sabda}$ is the Sanskrit equivalent for the Pāli term sadda. However, speakers of Northen Thai, Lao and Central Thai use the Sanskrit form for this word instead of sadda (sapda). In other passages of this manuscript the more common and indigenous Thai term gām is used.
} 
padassa haeng bot wā vipākadhammadhammāni panditanam an // veditabbo () nayava dadacchedo reu tang bot vipākadhammadhammānati dang $n i$ vipākadhammadhammāti // padassa haeng panditena an veditabbo // dhamm $\overline{\boldsymbol{a}}$ reu dhamma dang lāi vipākadhammāvipaccanasabhāvā lae/ / attho reu yathā //p// dhammä iti tang ni vipākadhammāti padassa haeng pot wā vipākadhammā panditena an veditabbo...vipākadhammadhammā $\bar{n} \bar{\imath}$ pen kammadhāreya ching () vakya mā dai pot samāsa wā vipākädhammädhammāa $n \vec{\imath} / /$ vipacanam vipāko vipacanam...[sic $]^{\prime 35}$

"vipāka (result) tends to have this adhivacana (designation), it is [related to] arupadhamma () nāmadhamma (the class of abstract concepts)...saddo (word) or word [in sanskrit] vipākadhammādhammā (states that have resultant quality) ${ }^{36}$ this means attho (the meaning), atthassaväcano(the verbal expression of the meaning), that which is said, atthavipākadhammadhammānāti (the states that have resultant quality with reference to the meaning), padassa (of the word), that is of the word vipākadhammadhammānati (the states that have resultant quality), panditena veditabbo (it ought to be known by the wise one), the chapter/section or all the words vipāka-dhammadhammānati like this vipāka-dhammadhammāti //

\footnotetext{
${ }^{35}$ There are numerous omissions of the long "a" in this section and the extra " $n$ " on the end of vipākadhammānāti seems to be superfluous. The failure to write the retroflexed "d" after the retroflexed "n" in the word panditena is also common in Northern Thai manuscripts.
}

(it ought to be known by the wise one) [that is] the [meaning] of [this] word, dhamma(state) or all the dhammas (states), namely, vipākadhammāvipaccanasabhā $\bar{a} \bar{a}$ (those things that have the essence of resultant quality and those states that have resultant quality) // attho (the meaning) or yath $\bar{a}$ (that which is so) // $\boldsymbol{p} \boldsymbol{e}^{37} / /$ dhamma iti [means] like this, the word padassa (of the word) of the word vipākadhammāa, (those states that are results) panditena veditabbo (ought to be known by the wise)...vipa $k \boldsymbol{k}$ dhammadhamma $\bar{a}$, (those states that have resultant quality) this [compound] is a kammadhäreya [a compound in which the first member modifies the second as an attributive adjective or as a modifying noun or as an adverb], that is ( ) vakya (a word) [in sanskrit] that can come, a word (that refers to a type) of compound, namely this vipākadhammādhammā // vipacanam (a result), vipāko (a result), vipacanam (a result)..."

Clearly, anyone who would listen to or read this passage would not forget the term vipākadhamm $\bar{a}$ or one of the

\footnotetext{
${ }^{36}$ The English translation of this word was drawn from Rhys Davids (1974: 2).
}

${ }^{37}$ Not only is the compound, either in larger compounds or alone, repeated several times, the translator/commentator uses the term pe which signals to the reader (usually not chanted outloud) that $\mathrm{s} /$ he should repeat the section that had been repeated several times before here. Since, the section I am translating comes from the beginning of the manuscript, it is unclear what section we are supposed to repeat here. The term $p e$ is found throughout the manuscript (f.ghā.5 for example) (which is quite rare in other nissayas) and it is similarily unclear which section should be repeated in those instances as well. 
compounds that incorporates this word. They would know how to read the compound since the translator/commentator explicitly defines it as a kammadhāraya (later on folio ghā.3. the reader is told to read the compound vipākadhammā as a bahubbïhi type of compound). The importance of the word is emphasized not only by its repetition, but also by the clause panditena veditabbo ("It ought to be known by the wise".) which is repeated several times throughout this section. Furthermore, when the commentator/translator moves on to comment/translate other sections of the $m \bar{a} t i k \bar{a} \mathrm{~s} / \mathrm{h}$ e continually returns to the compound vipākadham $\boldsymbol{m} \bar{a}$ or compunds like vipākasapdā (f.ghā.5) vipākajana (f.ghā.3) or lokiyavipākakathattārupa (f.ghō.v.34)[sic]. This method is repeated with other words drawn from the mātikā of the Dhammasangañi, like kusala and upādinna. The section ends with the translator/commentator giving a synonym for $\boldsymbol{v i p} \bar{a} \boldsymbol{k} \boldsymbol{a}$ and then repeating the synonym lest the reader/listerner forgets. What is strange about this section and several others like it in the Atțhakathamātikā Nissaya is that the semantic meaning of the term under discussion is not translated into the vernacular. Instead, the term is repeated, divided, combined with other words, and given alternate grammatical endings, but never actually translated. The vernacular is only used in this section to divide Pāli words and indicate how to read their suffixes. For example, haeng means "of" and indicates that the Pāli word that preceeds it should be read in the genitive. I included the Pāli terms in the English translation of this passages to demonstrate to the non-Pāli reader how a non-Pāli reader in premodern Northern Thailand may have read it, i.e., not for the semantic mean- ing, but to learn how to read Pāli compounds. We will see further examples of this type of grammatical commentarial service in the next section.

Repetition is a well-known feature of Pāli texts, especially mantra texts like the mangala sutta (which is one of the texts partially translated in the Sutmon Nissya). However, nissayas employ repetition in different ways. First, repetitive phrases in nissayas do not mimic the Pāli passages of the source texts being translated (if the source text is known or even exists). Second, repetition is not for the purposes of ritual praise, does not involve metre, and rarely is associated with litanies of qualities or directives. Finally, because they are vernacular translations that often, but certainly not always, lift Pāli words and phrases from the source texts, they do not simply provide vernacular glosses for the Pāli words, but actually write the Pâli words followed by their vernacular glosses and then often repeat this gloss within the context of the narrative, ritual, or ethical instruction. This repetition of both Pāli and vernacular words is seen clearly by focusing on what I call "reinforcement." Certain Pāli words are consistently glossed in nissayas, even though their gloss must have been commonly known. For example, in the Paññasajātaka Nissaya, the first person nominative pronoun aham is glossed dozens, if not hundreds, of times with the Northern Thai word $\boldsymbol{k} \boldsymbol{h} \overline{\boldsymbol{a}}$ (I). One would assume that once the word has been glossed once it would be remembered by the reader/audience or would only have to be re-translated occasionally; however, even in the last fascicle (10th) of the nissaya we read the phrase aham reu khä (I means I) numerous times. In the Madhurasachambu Nissaya, the Pāli second person nomi- 
native (and often accusative) plural pronoun tumhe (you all) is one of the many relatively simple words glossed dozens of times, with identical vernacular translations over fifteen fascicles. In the Saccasankhepa Nissaya, the word navaka (ninefold) is repeated seven times in less than two lines of one folio (f.gu.1-2). Other common words, like puggala (person), äha (s/he said), evam (thus), sutva $\bar{a}$ (having heard), are given the same verncaular gloss ad nauseum in many nissaya texts.

While there are clear pedagogical reasons for these rhetorical features, what is important now is to note that these narrative, ethical, grammatical, and ritual translations cannot be read as connected texts. The vernacular text is constantly interupted by glosses of Pāli words and phrases, and the excessive repetition serves to teach vocabulary and to display methods of rendering Pāli words within the bounds of vernacular phonetic parameters and syntactic patterns, rather than provide a simple and accurate vernacular translation of a source text.

\section{Commentarial Services}

From the brief overview of the rhetorical features of nissaya texts we could argue that nissayas should be placed under the rubric of a vernacular commentary, instead of a translation. Before providing an "accurate" translation of nissaya, some examples of the commentarial services the texts provide is required.

Nissayas are translations of canonical and non-canonical Pāli texts and, in some cases, vernacular narratives with no extant or known Pāli source text. However, these translations encompass many of the services most commonly associated with commentaries. Therefore, this section will look at the commentarial services of nissayas. Conversations with Charles Hallisey, Louis Gabaude, Donald Swearer, Prapod Assavavirulkaharn and Peter Skilling, and Lily de Silva's introduction to her edition of the Digha nikāyaatthakathā-tīkālīnattha vannanā, Paul Griffiths' Religious Reading and John Henderson's Scripture, Canon and Commentary have helped me isolate these commentarial services.

The first service of the nissaya is the glossing of individual words. As we saw above, this glossing is repetitive and runs throughout the translation. For example, the Madhurasachambu Nissaya from Wat Sung Men of Phrae province provides glosses of the most basic Pāli words, like aham and dhamma, as well as less commonly known words like parasuddha [parisüdha](pure). The glosses range from simple synonyms in the vernacular to long explanations incorporating other Pāli words (which may or may not be glossed). The Dibbamon (Dibbamanta) Nissaya from Wat Mai Suvañnabhūmarām in Lū'ang Pabāng, Laos operates more like a bi-lingual dictionary than a textual translation. This is the function usually associated with wohära or $s a b$ texts, but some nissayas provide this service, and indeed some nissayas are titled nisrai wohān or nisai $s a b$ in their colophons. ${ }^{38}$ For example, one passage reads:

"siddhi man gong kō dì kammaṃ an ko geu wā kām kō dì dhammam an kō geuwā dhamma kō dì saccam an kō geu wā sacca kō dì nibbānam an geu wā

\footnotetext{
${ }^{38}$ A study of these types of texts remains a
} desideratum. 
nirabbān..."

"siddhi (means) powerful, kammam is action, dhammam is dhamma (law, truth, saccam is sacca (truth), nibbānam is nibbāna..."(f.1.v.1-2)

This passage is a clear example of the many ways Pāli words can be rendered in Lao. First, siddhi is given the Lao gloss of man gong (strong/powerful). Second, kammamis glossed with its Lao derivitive $k \bar{a} m$. Third, the glosses for dhammam and saccam suggest that there is no Lao lexical equivalent (although there are several for saccam and dhammam is usually written $d \bar{a} m$ in Lao) and simply removes the ending (accusative singular masculine) of the Pāli word (dhammam is dhamma (and) saccam is sacca). However, the last word (nibbānam) is translated with an apparent hybrid Sanskrit and Pāli lexeme (nirabbān) ${ }^{39}$

Several pecia (maks) of the DhPN usually only provide brief glosses for individual Pali words in the Dhammapadaatthakatha, consisting mostly of synonyms in Lao or Northern Thai; however, there are occasionally different glosses for the same word and/or providing a definition for the Pâli word in question that makes sense only in the context of the particular story. For example, in the Dhammapada Nissaya (mak 7), there is a gloss for the word disvā, that reads: $k \bar{o}$ hen yang khao dip kao ngām sōem chum ("this means (s/he) sees/saw new (and) excessively beautiful rice").

These extended glosses which move many nissaya texts out of the realm of translation and into the realm of commentary are similar to the early Chinese translations of the
Asțasahāśrikaprajñ̄pāramitāsūtra (Asta), examined by Lewis Lancaster in his 1968 dissertation..$^{40}$ Lancaster notes that Chinese translators often inserted their own interpretations and additions into the Asta when translating lists or litanies. This litany expansion is seen in the nissaya of the Dhammapadaatthakatha \#252. There is a list that mentions beautiful garments, jewels, etc. removed magically from a ram's mouth. In the nissaya translation, these items are specified and expanded to include local terms for specific fabrics and the mention of silver as well as gold. Still, the list of foods taken from the ram's mouth is shortened, and ghee and sesame are not mentioned. This may account for the general lack of sesame and ghee in a Lao diet (although there are Lao words for these foods), and therefore a lack of understanding of their value by the author or audience. The same explanation can be given for the addition of specific fabrics, since silk and cotton production and the artistic skill associated with it have been extremely important to the Lao economy and symbols of its local identity for centuries.

The second commentarial service is grammatical explanation. ${ }^{41} \mathrm{~A}$ Kammavācā Nissaya manuscript from Wat Pichai, Lampang Province, Northern Thailand reads: "sammāpetva $\bar{a} \bar{o}$ hai pati ao dūai dì lae hai mì chai-ya an

\footnotetext{
${ }^{39}$ These hybrid Sanskrit and Pāli lexemes are very common in Thai, Northern Thai and Lao and Nissayas often gives both the Pāli and the Sanskrit spelling or a hybrid of the two when they gloss words from Pāli. ${ }^{40}$ Lancaster (1968).

${ }^{41}$ Oskar von Hinüber has written extensively on the subject of the Pāli grammar of Northern Thai manuscripts. See especially (1983):75-88; (1987): 111-119; (1988a); and, (1988b): 173-74.
} 


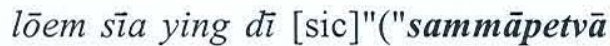
means that he caused the pati (lord) to hand (it) over (it immediately) and he caused (him) to have a complete and successful victory")(f.kāi.v.2). The word hai indicates the causative in Northern Thai. In the Dhammapada Nissaya (mak 7) (f.kāe.v.5), there is a passage that reads: alamkaritu $\overline{\boldsymbol{a}}$ ko bradap yang dūai khrū'ang bradap thang $m \bar{u}^{\prime}$ 'an lāeo ("alamkaritv $\bar{a}$ means (she) adorned (herself) with all types of ornaments"). The word $l \bar{a} e o$ is a word that, if placed at the end of a phrase, indicates that the verb (s) in the phrase must be read in the past tense. Most grammatical explanations are of the locative, ablative or nominative plural, using the words nai (in), chāk (from) or $x \bar{a} k$ (Lao) and thang lāi (all/many) respectively. Furthermore, the imperative is consistently indicated with the word chu'ng or chong (Lao). However, there are dozens of examples of Pāli words, not in the nominative singular present, that are never grammatically indicated in the vernacular. This could indicate a poor knowledge of Pāli grammar, but in most cases the grammatical form of the Pâli word seems to be understood by the translator and simply not indicated because it can be understood in context. This follows Lao and Northern Thai grammar, which only indicate tenses and modals if not apparent from the context. Words like cha (will/shall) and lāeo (already/in the past) are often considered superfluous.

Although most grammatical explanations are relatively simple, there are often efforts to provide more extensive explanations. One passage from the Sutmon Nissaya is particularly lengthy. I have translated a section of it as follows: "corato wā chōn thang lāi kō dì manusato wā tae chon kō dĭ amanusato wā tae pāi haeng pi iti (??) aggito wā tae fāi iti uddakato wā tae nām iti

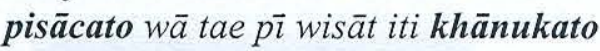
lak tām iti kaṇ̣akato... "[sic]

"corato means all those who are thieves, manusato means from people, amanusato means from the danger(??) of ghosts, aggito means from fire, uddakato means from water, pisācato means from demons, $\boldsymbol{k h}$ ānukato means from an underground (??) root, kaṇqukato means..."

Although this section of the Sutmon Nissay a claims to be a translation of the Mangalasutta, these words are not found in the Mangalasutta. Moreover, the "-ato" (from -atas) ending usually signifies the ablative. ${ }^{42}$ However, reading the Pāli words in the ablative leads us to wonder why corato (the first word of the list) is translated as a nominative plural. However, the scribe could have accidentally omitted the tae following corato, which would solve the inconsistency. I am genuinely perplexed by this passage's meaning, especially since it is supposed to be part of a translation of the Mangalasutta, and these words with these endings are not found in any addition of the sutta of which I am familiar. Still, what is important for the purposes of this paper is that the author seems to be presenting us with a lesson on a particular grammatical form and seems to be more concerned with that grammar

${ }^{42}$ K.R. Norman was one of the first to note the particularities of Northern Thai Pāli; namely: "unhistorical gemination of consonants and the converse, unusual retroflexion of dentals, and unusual spellings." They are genuine characteristics of Pāli as it was spoken in Northern Thailand in the sixteenth century" Norman (1983: 144). 
lesson than in providing an accurate translation of a source text. Certainly, reading passages like this would ingrain the association of the "-ato" suffix with the ablative marker in Northern Thai tae. If we look at the manuscript pedagogically, we may seriously suggest that this passage was designed to be an audiencecentered grammar lesson, drawing material from a source text. In this way, the source text becomes the servant of the translation and reverses the general notion of the superiority and inviolability of the "original" or source text. As we saw in section I.B., the Atțhakathāmātikā Nissaya, the source text is employed to teach the reader/ audience how to read compounds and the translator only gives the semantic meaning of the Pāli terms in the vernacular when it serves this grammatical end.

The third commentarial service is the clarification of word order. The beginning of the Dhammapada Nissaya (mak 7) re-orders the words of the initial sentence of a verse in the Dhammapadaatthakathā. The sentence reads: "sudassan ti imam dhamma desanam Satthā Bhaddiyam nissāya Jātiyāvane viharanto Meṇdaka sețthim ārabbha kathesi" (" 'Sudassan' the teacher gave this dhamma-sermon while living in the Jātiyā forest near the town of Bhaddiya about mendaka the Wealthy Man"). The nissaya translates these words in an entirely different order (Just as I just did in rendering the passage into English!). As in Lao syntax, the time and the place are usually the first things mentioned when relating an event in the past. Therefore, the nissaya begins by translating viharanto (living/residing) and the last part it translates are the words kathesi and dhammadesana. This in no way takes away from the meaning of the Pāli sentence, but like any transla- tion, re-orders the words so as to make the translation easier to understand to a local audience (see: f.1.1-3). Throughout nissayas, this manipulation of Pāli word order is commonplace. However, in order to identify where a nissaya is changing the word order of the source text, that source text needs to be identified, which is (as we will see below) often difficult if not impossible. Moreover, when the source text can be identified, the translation is often simply a translation of some selected passages or words, or a summary of the source text that is not extant in Pāli or perhaps was written by the translator himself. The Atțhasālinī Nissaya is a good example of the former and the Nāma Nissaya, the Madhurasachampū Nissaya, and Lokabhāsā Nissaya are good examples of the latter.

The fourth commentarial service is as a thesaurus of Lao or Northern Thai vocabulary. Often times throughout nissayas a Pāli word is given several definitions or at least a list of synonyms. The Atthasālin̄ Nissaya (mak 8) from Chiang Mai, for example, gives numerous different definitions for the word dhamma. In the Dhammapada Nissaya (mak 7) we find a translation of the word bhariy $\overline{\boldsymbol{a}}$ (wife)(f.1v.1). This is followed in Lao with nāng an pen mahesī su' wā nāng chandapadumā iti ("an older, upper-class female, that is a mahesi, whose name is Madame Candapadum $\bar{a} ")$ Here, the Lao provides a simple synonym for bhariy $\overline{\boldsymbol{a}}$ with $n \bar{a} n g$, which does not specifically mean a married woman or wife, but often is a title only given to married women. There are several words for wife in Lao, mia, pariy $\bar{a}$ (from bhariy $\bar{a}$ ) and fãen to name a few, but this author decided to refer to this wife by her title and a very important title at that. Nāng is followed 
by mahesi. Mahesi comes from the Sanskrit word for female buffalo and is often translated as queen. It is uncommon in Lao, but would be spelled and pronounced the same way in Lao. This would seem a strange choice as a definition for bhariya $\bar{a}$ (kalatta is also common in Southeast Asian texts) but could indicate an effort on the part of the writer to teach more vocabulary to the audience or the scribe or student monk who may have been taking dictation. Furthermore, mahes $\vec{i}$, being a Sanskrit word might have also added a sense of importance (as Madame does in English). Mahesi is not mentioned in the Dhammapada-Atthakatha, from which this nissaya has been translated (i.e., the manuscript that the PTS used to assemble this critical edition of the $D h P A)$. Finally, the Lao specifies the name of this woman as she relates directly to this story; namely, nāng chandapadummā.

In the Nissaya Nāma from Wat Phra Dhāt Chōmgīrī in Chiang Mai we find other lists of vocabulary that blurr the line between a theasurus and a dictionary. One example reads: "itthi rêu p $\bar{u}$ ying //vadhu rēu lüksaphai //bhikkuni rēu bhīkkhuni tang itthivadhu bhikkhunï long sichū (??) hāeng pubba āo tth āo dh āo long wai ão $i$ wai..." ("itthi (means) woman, vadhu (means) daughter, bhikkhuni (means) nun, all of these, the itthi, the vadhu (and) the bhikkhuni come (??) previously (one) took 'tth' (and) took dh (and) placed them (??) (and) took 'i' (and) placed it...").(f.1.3) This example (which is unclear and haphazardly written) not only demonstrates that some nissayas provide lists of semantically related lexical items, but also that they offer instructions in how to write or, more likely, pronounce the words. Although
I am unsure, the passage that follows the list of "woman, daughter, nun" seems to be the translator's note of how the words can be spelled differently (i.e., replace "tth" of itthi with "dh"). Still, the fact that "tth" is in itthi and "dh" is in vadhu and " $i$ " is in bhikkhuni might suggest that these were abbreviations for these words. There are dozens of other examples of these synonyms that demonstrate how a nissaya could have worked as a thesaurus or a dictionary for students learning how to listen to,read, and/or write in Pāli and the vernacular.

As we saw in the Atthakathāmātikā Nissaya, the word vipāka was given the synonym vipaccanam. Later in this manuscript, (f.ji.1) in another long and repetitive passage explaining how to read different types of compounds, we find the term sahāvicāara [sic] translated with the synonym savitakka. The translators and/or commentators of Pāli texts added new Pāli words to the source texts on which they were commenting.

There is another commentarial service that I have only found in the manuscript of the Madhurasajambu Nissaya. ${ }^{43}$ There, several Pāli sentences are given, followed by Northern Thai translations. What is interesting is that the Pāli sentence given seems to be abbreviated with the endings of individual words dropped off and a system of sandhi, developed solely for this text. Although I do not have, and actually doubt there exists, an "original" Pāli text for this nissaya, ${ }^{44}$ what source the author of the

\footnotetext{
${ }^{43}$ In the Atthakathāmātikā Nissaya, we find a similar type of commentarial service which instructs the reader/listener how to understand sandhi rules in Pāli. Folio ghā, line four explicitly mentions the reason the long " $\overline{\mathrm{a}}$ " is found in a compound.
} 
nissaya was drawing on was either from a very poorly written Pāli text, was written by the author of the nissaya him/ herself to demonstrate his talent in clarifying garbled Pāli, or was a pedagogical technique designed to demonstrate several ways of writing Pāli words or how to manipulate Pāli sandhi rules. For example, one Pāli sentence reads: "khemimaggayam kampiya rúkkha rucei dāmana manipabhäbhidhammāgga samam manamānicca" (MRChNP-1-f.ka.v.1). This verse makes little, if any, sense as it is, although individual words like rukkha, magga, abhidhamma, etc. can be isolated. But without grammatical endings, it would render this passage a litany devoid of syntax. Still, the author of the nissaya divided the words and provided endings. Her/his translation reads:

"khemam maggam yang hon thāng an brasōet siddham an sāmret // yam mak wā yodhammo ree dhamma an dai kāppaya rukkha ruci dadāma $k \vec{\imath}$ bha $k^{45}$ an rung rōen an hai lāeo yang () dang chai mak pen dang ton kārabbi dip nan aham rị khaa namāmi kaw wai dhammạ̣ yang dhammā aggam an asamam an hā dhamma an ü'n cha sem bo dai niccam thang $\operatorname{mu}^{\prime} a$ lāe santi $n i$ () yam samgatatan( )m pavaram visuddham...."(Phūk 1.f.kā.v.3-f.kā.v.5)

This passage is unclear due to damage to the manuscript, but a provisional

${ }^{44}$ The folktale is described by Dr. Balee Buddharaksa and the Encyclopedia of Northern Thai Culture (Saranukrōm watanadham thai phāk nēua) native to Northern Thailand and existing only in the vernacular, it is related to the Lao story of Ōm Lōm Dāeng Khieo, which has no extant nissaya. ${ }^{45} \mathrm{~K} l$ is a common (mis)spelling for $k \bar{o}$ is this manuscript. translation can be given that reads: "khemam maggam' means the way that is excellent. 'Siddham' means completed. 'yam' means 'tends to.' 'That dhamma' is known as any dhamma whatsoever. 'Käppaya rukkha ruci dadāma' means a forest that is brilliant that gave (), he concentrates his own (mind) (??) on that light. 'I' means I. 'I honor" means "to bow to the dhamma, that 'dhamma which is known as the highest', that which is excellent, 'that which is incomparable' [meaning] [one] is unable to find another dhamma which is better. 'Permanent' [means] all the time and peaceful. ( ) 'for that one which is well-joined, excellent, (and) pure."' Clearly, this passage was not meant to be read as a connected or coherent narrative, but rather provides translations of rather disjointed Pāli phrases. What is important here though is not the semantic resonance of the Pāli or the Northern Thai translation, but instead the way the author of the nissaya provides declension markers for Pāli words without markers, most often placing them in the accusative singular masculine. Furthermore, he "corrects" or provides alternate spellings for certain Pāli words, like writing khemam for khemim, pavara for pabhäbhidhamma, and ruci for rucei. The clarification of sandhi is also interesting, because pabhābhidhamma is divided into two unrelated words pavara and visuddhim. Manamänicca is simply rendered as niccam. This second example shows how important sandhi is in understanding this passage, because the author of the nissaya seems to translate the Pali to say that dhamma is permanent, which defies one of the most important teachings of canonical Theravāda Buddhism -- the dhamma is impermanent. This Pāli passage and its translation would make any good Sri Lankan or British 
Pāli scholar shudder because both the Pāli sentence and its translation butcher canonical Pāli grammar and spelling. We could simply relegate this manuscript to the dust-bin as an example of the poor Pāli training in medieval Northern Thailand or designate it as the product of an exhausted and amateurish scribe. This I believe would overlook some of the most significant facts about the languages of Northern Thai and Pāli in Northern Thailand and the creative and pedagogical aspects of translations in the region in the pre-modern period. Moreover, since we have dozens of examples of "good," normative Pāli in this very nissaya and in other nissayas and in other manuscripts from the same temple written around the same period, we cannot simply say that the training of this particular author was poor or that the author was completely unaware of his unorthodox translation. In the process of dividing words, the author does not simply add endings and split up the Pāli words and provide vernacular translations. He adds Pāli words that are not found in the Pāli sentence he is translating. Moreover, he not only adds Pāli words and ignores others, he provides vernacular glosses for those Pāli additions. Therefore, as he translates, he is composing a new Pāli text. This is more than a translation. It is a commentary on his own translation and not one of any "original" Pāli source text. These "notes" of the translator provide access into the largely unknown world of pedagogical methods, manuscript production and hermeneutics in medieval Southeast Asia.

\section{From Commentary to Canon to Curricula}

From our brief examination of the source texts, commentarial services and rhetorical style of many Nissaya manuscripts, we can tell immediately that they incorporate many of the features of what Buddhist Studies scholars include under the rubric of "commentary." For the last twenty years there has been a growing interest in the study of commentarial practices in Religious Studies. In 1978, Jonathan Z. Smith noted that all religious writing was in someway commentarial, but there had been no serious study of what features were common to commentaries across religious traditions, how commentary defined a canon and what assumptions the writers of commentary make about the "original" text. ${ }^{46}$ Paul Griffiths, Jeffrey Timm, Laurie Patton, Steve Collins, Charlie Hallisey, Karen Derris, Anne Balckburne, John Henderson and others have taken J.Z. Smith's call for a more in-depth study of commentaries seriously, but the study of commentary in religious studies, and especially in Theravada Buddhist Studies, is still an underdeveloped field of inquiry. Paul Griffiths sees commentary as the quintessential way to read "religiously." Commentary is an active process, or what John Dagenais calls "lecturature." Commentary is done for the purpose of "altering the course of the reader's cognitive, affective, and active lives by the ingestion, digestion, rumination, and restatement of what has been read." 47 Reading "specialists" in many traditions, especially Buddhist India, guided readers through their own particular interpretation of a "canonical" through commentary. Commentary is thus a "beliefforming practice." 48 Therefore, in order to understand the particular epistemology of an individual religious commur-

\footnotetext{
${ }^{46}$ Smith (1978: 299-300); and, (1982: 45).

${ }^{47}$ Griffiths (1999: 54).

${ }^{48}$ Ibid.: 74.
} 
nity, we must look at their commentarial methods to understand how a text was understood at different times by different communities. Griffiths also provides his own definition for what constitutes a commentary, that being: 1) apparent and direct relation to some other work through direct quotation, paraphrase, or what Michael Fishbane calls "multiple and sustained lexical linkages;" and, 2) these linkages should "quantatively" dominate the text, such that, if they were removed, the work becomes incomprehensible. From the brief examples I have given above, it should be clear that nissayas are a form of commentary according to Griffiths definition. ${ }^{49}$ However, Griffiths is generally writing about commentaries written in the same language as the object text (i.e., Hebrew commentary on the Hebrew Bible, or Sanskrit Commentary on Sanskrit Buddhist texts). However, a commentary in one language on a source text of a different language does not necessary change the style or purpose of the commentary. Furthermore, some of the nissayas we have seem to be written on Pāli texts that never actually existed prior to the nissaya. They often have multiple and sustained linkages to a source text, but that source text is either unidentifiable or almost completely divergent from any extant version of the source text. Or the nissaya follows a known source text at points and then makes long detours away from the source or makes a conglomerate vernacular commentary on an idiosyncratic, ad hoc anthology of excerpts from various source texts. These

\footnotetext{
${ }^{49}$ Griffiths takes many of his ideas about what constitutes a commentary and different commentarial strategies from John Henderson's comparative study of Confucian, Midrashic, Sufi, Greek and Sanskrit commentaries. See especially chapter five of Henderson (1991).
}

facts, combined with the fact that nissayas are most often written on noncanonical and even non-Pāli texts, shows that if nissayas are to be considered commentaries, then they do not reinforce the closure and boundaries of the Pāli canon, but actually work to expand the canon. Furthermore, nissayas expand the purposes of a commentary as: explaining a text, justifying its importance in the tradition, and absorbing and replacing the original text.

Three other recent works on commentary are also important to the study of nissayas. Laurie Patton wrote an intensive study of the Brhaddevata and its multiple commentarial services. By looking at the nirukta, anukramani and $m \bar{u} m \bar{a} m s \bar{a}$ traditions of ancient India, she shows how the Brhaddevatā was a creative act that emphasized certain parts and aspects of the Rg Veda over others. ${ }^{50}$ It also reinforced the sacred and canonical status of the $\mathrm{Rg} \mathrm{Veda}$. Patton, following Bruce Lincoln, J.Z. Smith and Brian K. Smith, shows how the Brhaddevatā formulated taxonomies of important words and ideas, and thus can be seen as developing the categories of ordering information, and helps us understand the epistemology of a particular community. ${ }^{51}$ By emphasizing certain parts of the $R g$ Veda and setting them out in lists, the Brhadddevatā was able to keep the $R g$ Veda relevant and viable in a different historical period. Drawing on work done by Gananath Obeyesekere and Lee Yearly, she shows how the composers of the Brhaddevatā used and manipulated the $R g$ Veda to serve the social and intellectual needs of their time. Numerous points in Patton's work are helpful for the study

\footnotetext{
${ }^{50}$ Patton (1996: chp. 2).

${ }^{51}$ Ibid.: 27-28.
} 
of nissaya as a type of commentary, especially her thesis regarding the manipulation of a canonical text for different historical circumstances. Looking at nissayas allows us to expand this thesis in two ways. First, the evidence of repetitive glossing, the introduction of new vocabulary as additions to stock phrases of the nissaya texts shows that the composers of the nissayas wanted to use the commentary as ways to teach language and help scribes or the audience remember stories. This defined what was important to know as a Buddhist in that community. Second, and more importantly here, by seeing the nissayas as primarily educational, we can see how the very choice of what texts to translate and comment on was a way of serving the intellectual and social needs of medieval Laos and Northern Thailand. For example, why would the composers of the Dhammapada Nissaya choose the stories to translate and comment upon? Why do most stories chosen by the Dhammapada Nissaya writers involve stories of wealthy people finding magic stones or bowls, miraculously becoming rich or controlling famines and wild animals? Why do other nissayas, like the Kammavācā Nissayas, emphasize the status of certain Southeast Asian tribes or social groups over others, or teach how ordination cures epilepsy? Why was the apocryphal Pañ̃̃āsa Jātaka collection a subject of a nissaya and not canonical Jātakas, and why did they only organize the stories the way they did? Why does the Madhurāsachambu Nissaya have long lists of animals inserted in the middle of the story? The choice of what texts and what words from a particular text to comment on and translate in nissaya form can tell us a great deal about the needs of the communities that composed them and what aspects of Buddhism were deemed more important and most necessary to teach, especially in the vernacular. If commentaries define what is considered "canon" by a particular community, then nissayas define a set of texts that were considered "canonical" for the sake of Buddhist education.

Nissayas are evidence of what we can call a type of curricular canon operating in pre-modern Northern Thailand and Laos. This canon did not exist in the minds of the writers and audience, but these texts were the ones taught and copied in the vernacular. They can be called vernacular commentaries on an ad hoc canon composed of Pāli canonical material, Pāli commentaries, vernacular folktales, apocryphal Jātakas, locally- assembled anthologies or collections of prayers. This certainly stretches and qualifies our understanding of commentaries. Since certain types of texts were used for different purposes (i.e., parittas for life-cycle rituals and warding off bad spirits; jātakas for calendrical rituals such as New Year festivals, weekly sermons, calling for rain, visakha puja, etc.; kammavācās for ordination ceremonies, the establishing of a new monastery, etc.) we can say that there were multiple overlapping canons of texts. Nissayas I believed formed one of these "practical canons." Since nissayas clearly incorporate pedagogical methods and may have been employed to teach both vernacular and classical vocabulary, syntax, phonetics, etc., I would venture to call them a type of curricular canon. Still, I do not want to suggest that nissayas were the only texts used in the day-to-day education at a monastery. There are other types of Pāli and vernacular texts similar to the nissayas, like sabs and wōhāns, that need to be looked at to determine if they 
incorporate similar pedagogical methods. Furthermore, many of the manuscripts in regional archives and monastic libraries have Pāli canonical titles, but on further investigation many are actually vernacular summaries or vernacular commentaries. I merely want to suggest that nissayas could have served as notes and guides for sermons and grammar lessons (either to fellow monks or to a lay audience). The examples given in the section on rhetorical style and object texts support this understanding. Nissaya traditionally means "support." It is, of course, an old term meaning, on the one hand, the relationship between a young monk or novice and his teacher (āchärya or upādhāya), or on the other hand, the period of training, support or dependence of a newly ordained monk, usually lasting between five and ten years (Mahāvagga I.32,1; I.54,4; I.1,36; V. 1,5; V.4,2). Nissayas were just that -- supports or guides written by a teacher for one or a small group of students to guide their translation and study of Pāli texts, and thus enable them to not only learn how to read and write Pāli and the vernacular, but also enable them to explain Pāli concepts for the purpose of a sermon to fellow monastics or to a lay audience.$^{52}$ Nissayas are not condusive to reading as a connected narrative, because they are interspersed with Pāli words and because of their definitions and short explanations of their grammatical forms. They are disjointed texts, and to read them straight through would be like reading the "Anna Livia Plurabelle" episode of Joyce's Finnegan's Wake, if every third word was followed by its dictionary definition in Italian. They do not read like sermons, stories or instructions, but as notes for telling stories, giving sermons, or explaining instructions. They are supports for those who have to read and explain Pāli texts to an audience. The choice of the object text depended on its popularity for use in sermons and ceremonial chanting, while the purpose for writing it was to instruct its readers/ audience on the meanings of Pāli words and phrases. I doubt any nissaya was read outloud verbatim as a sermon or as a narrative, but instead was a reader's/ teacher's guide to consult when explaining the meaning of words and phrases in a popular narrative. Since collections of manuscript. have vernacular translations of texts, like the Dhammapada, Kammavācā, Sattaparitta, etc., as well as Pāli and vernacular commentaries, there is no reason to have a separate genre of manuscript called nissayas unless they served a separate purpose. ${ }^{53}$ I contend that while translating a Pāli text a student read alongside the object text as a running commentary and translation. But since the nissayas often diverge widely from any source text that scholars have come across, they may have been merely inspired or influenced by the structure, ideas and lexicon of a particular source text. The reason for having a middle-stage of translation between a Pāli object text and a straight vernacular translation was to be able to explain the Pāli text to yourself and to an audience -- a student's guide and a teacher's handbook. Nissayas (or at least the wide selection of nissayas I have examined) most likely served two pedagogical functions. First, they were assignments given orally in monasteries so the student monks could learn Pāli vocabulary in a slow, repetitive way while learning how to use those new words in context and within a

\footnotetext{
$\overline{52}$ Oskar von Hinüber suggested to me that nissaya could perhaps be derived from the fact that they "lean on" Pāli texts.

${ }^{53}$ I thank Prof. Michel Lorrillard for a particularly insightful discussion of this issue.
} 
vernacular syntactic structure. Second, they were used as guides on how to explain certain Pāli texts, perhaps for the purposes of a sermon (this is how monks in Laos use them today and how sermons in Central, Northeastern and Northern Thailand operate). This educational purpose might account for the relatively poor quality of the manuscripts (they lack illustrations, carved and ornamented wooden covers, and elegant lettering, and numerous interlinear and marginal corrections written by the original scribe of the manuscripts in question). It also might provide an explanation of the lack of multiple copies of any individual nissaya manuscript. Indeed, these manuscripts might not have been intended as texts to be presented to royalty or other temples or as items of display at a monastery, but instead are the remnants of the "homework," lecture notes, and marginalia of teachers teaching how to translate, or as notes for or recordings of sermons dictated by a teacher to a student.

Could nissayas be the result of a long period of experimentation to develop superior pedagogical techniques or the result of an unconscious internalization of the best methods to format a Pāli or vernacular text so as to be easily learned and remembered by the student, whether it be a single monastic scribe or a lay audience? Nissayas may have been consciously planned in order to be an effective pedagogical technique for presenting new information and teaching language. Or, perhaps, the pedagogical methods found in nissayas are the result of influences of traditional commentarial styles in Sanskrit and Pāli from South Asia combined with local literary experiments with alliteration, repetitive patterns, etc. which served as a model for composing instructional manuals for giving sermons and language "textbooks" or "readers." For example, two of the most well-known and oft-printed Pāli prayers in Thailand and Laos are the Sambuddhe and the Buddhābhigiti verses. ${ }^{54}$ Both of these are found in virtually every version of standard chanting books in Thailand and Laos and both have repetitive phrases that frame new information with every verse. Dozens of examples of other Pāli prayers in verse could be cited, and theirs style could have influenced the prose structure of nissayas. Still, while interesting, this "similarity" is too general to be useful.

There are many other possible sources for the pedagogical, repetitive, and reinforcing style of nissayas, and some modern teaching methods that mimic nissayas, that can be more systematically examined. For example, the general style of sermons in present day Thailand and Laos supports the contention that nissayas were primarily pedagogical and that nissayas could have been inspired by oral sermons. We have few examples of sermons in Northern Thailand and Laos from before the late 19 th and early 20 th centuries. From my cursory reading of a number of desanā (sermon) manuscripts, it seems that they are very similar with the nissayas, at least in the manner of "lifting" individual Pāli words from a particular text and employing several methods to explain the word in the vernacular. Furthermore, one manuscript from Laos is titled a "nisai-desana." ${ }^{55}$ Still, the study of desanā as a genre of manuscripts remains a desideratum.

The "Phra Dhammadesanā

${ }^{54}$ See for example the Suat mon chabap lü'ang (1975); and the Suatmon Mü'ang Nü'a chapab sombūn (1994). 
Piyakaraṇakathā" by Phra Kaw̄iwarañān and Phra Priyatthïrakhun's "Phra Dhammadesanā Dhammacārīkathā" are transcripts of two modern sermons that are based on the repetitive and meticulous (but often fanciful) translations of individual Pāli words and phrases. It also may be noted that audiocassettes of sermons or nightly radio and television broadcasts of sermons in Thailand generally have the style of repetitive lessons based on the creative and multiple translation of Pāli words. Taped sermons by the late Lū'ang Pū Tō of Bangkok and Lü'ang P $\bar{u}$ Chā from Ubon Rachātāni Province are very common and particularly good examples of this style. The infamous disrobed monk, Phra Yantra of Kanchanāburi Province, now living in exile in California, would often base whole sermons on the translation of one Pāli term like "tañha ." ${ }^{56}$ This repetitive style of translating one term in slightly different is not limited to sermons by monks. On the eve of his 74th birthday, the King of Thailand gave a speech, lasting approximately one hour, on various subjects including a development project in Prachuap Khiri Khan Province and about taking care of dogs. When lecturing the government on the subject of cooperation and equality among its members, he translated the English idiom "double standard." $\mathrm{He}$ spent almost 25 minutes breaking down the word into its components and trans-

${ }_{55}$ See the nisai-itipiso-desana $\bar{a}$ (ms. 0601 8505003 05) from the Luang Pabang Museum in Laos composed in CS 1199 [AD 1837]. The early date of this desana and its rare title in comparison with other desan $\bar{a}$ could suggest that this is evidence of a transition of texts titled nissayas and texts titled desana $\bar{a}$ since nissayas declined in production after the 1840's and desana increased. Investigating the differences between desana and nissaya would require a separate study. lating them in different ways and relating this idiom to certain practices of the Thai government. The next day, I asked people in my Bangkok neighbourhood what they remembered about the speech and, besides the humorous story about the dogs, they all could recall the English term "double standard." There were numerous newspaper articles that

${ }^{56}$ These cassettes can be purchased at many temples and at any religious bookstore in Thailand. This style of giving sermons can also be observed by attending most sermons on full and half moon days in Thailand or Laos. As a side note, I recently went to the two major monastic universities of Thailand and Laos to inquire about which texts they used to instruct Pāli. At Wat Ong Teu in Laos, they do not use a standard Pāli grammar text, but instead, the instructor reads Pāli passages and translates them into Lao for his students. Translation is more at the level of memorization than detailed explanations of grammar or linguistic issues. The text he was using for the lesson on the day I interviewed him was an excerpt from the Dhammapada. At Wat Borworniwet (Mahāmakutarājawidyalai) in Bangkok, instruction generally takes the form of memorization as well; however, there is a series of short paper-back Pāli grammars for novices. I am still unclear on how they are incorporated in a Pāli lesson and need to investigate further. It may be noted that these grammars were hard to locate at the Wat Borworniwet book store and when I ask about what texts novices and monks use for Pāli study I was given a few bi-lingual liturgical texts with Pāli and Thai in two columns. These books are very prevalent at the bookstore and would be too numerous to list here. However, the most common ones would certainly be: Phrakhrūrunathamrangsì' Monpītī blāe samrap Phrabhiksusāmanen lāe Phutthasāsanikachon tua bai (Bangkok: Wat Arunarārāchawarārām, 2534 [1991]) and the Suatmon chabub lu'ang blāe (Royal Chanting Book Text and Translation). 
discussed the King's use of the term and two weeks later it was the subject of a panel discussion at Chulalongkorn University, with four speakers discussing the practice of "double standards" in Thai society. Clearly, the term was repeated hundreds of times, and given multiple translations and interpretations. This is not to say that basing a lecture, sermon or meeting on the translation of a term is unique to Thailand, but that it is a standard way of structuring a sermon or speech, and this gives us a clue as to how to read and explain the excessively repetitive rhetorical style of nissayas. Whether sermons in Thailand and Laos were constructed in this way and in turn were a source for the methods found in nissayas or vice versa is impossible to say, but the similarities are striking.

The repetitive style of commentaries and sub-commentaries, like the Atthasālin $\bar{\imath}$ and the Atthasālan $\bar{\imath}$ Atthayojanā that were mentioned above, also are a possible source of the nissaya rhetorical style. For example, a passage from the latter reads:

\section{"vā aparo nayo ye akusalā kucchitena $\bar{a} k \bar{r}$ rena sabhāvena sayanti pavattanti iti te akusalā kusā kupubba si saye"}

"Another method [for reading the word akusalā in the sentence]: 'those things that are supported by and sustained with a disposition [characterized] by vile modes of acting;' [in this example] akusala is formulated from 'ku' as the first member and with the root 'si' in the sense of 'saye' (to sleep)." ${ }^{57}$

This passage goes on to give several methods for reading the words kusala and akusatā. Although more systematic in its explanation of the word akusalā than most nissayas would be (except for the Nāma Nissaya which employs a similar folk etymological method by breaking individual terms into their component syllables), the repetitive style and focus on individual terms might have been a source for nissaya methods of commentary, which could have subsequently influenced translation methods.

Still, this feature of the nissayas is also closely akin to a little-studied linguistic feature of Lao and Thai poetry and vernacular religious texts known as "rōi (hōi) gāeo." Lao linguist and literary historian, Mahāsila Wirawong, is the only scholar I am familiar with that has seriously discussed this textual practice. ${ }^{58}$ He shows that it was common for local writers to string an alternating and repetitive series of vernacular and Pāli words together like "jewels on a necklace" (i.e. $h \bar{o} i \mathrm{~g} \bar{a} e o$ ) for reasons of education and aesthetic appeal. The $h \bar{o} i$ gāeo method of composing bi-lingual texts in the region is most likely the result of the mixing of traditional Lao and Northern Thai poetry (that works on the scheme of a repetitive pattern of alliteration, tone alternation and rhyming) with Pāli word commentaries. The result is a unique linguistic feature that allows the reader/audience to easily remember certain Pāli and vernacular lexical items through repetition, alliteration and rhyming. Moreover, the hōi gāeo

\footnotetext{
${ }^{57}$ Atthaasālinī Atthayojanā. (Phumipala Edition. Bangkok):111. I thank Prapod Assavavirulkaharn for helping me read this passage.

${ }^{58}$ Wirawong, Mahasila (1995: 4-5). In modern Thai the meaning of roi gāeo has changed and now simply means prose. This is probably because the earliest non-verse vernacular literature, of which nissayas are evidence of, was distinct from Pāli and early vernacular epic poems and verse dramas.
} 
system combined with the type of excessive glossing shown above reflects one of the pedagogical functions of nissayas: to tell entertaining, melodious stories or give ritual instructions or ethical sermons while teaching Pāli and vernacular vocabulary and certain important Buddhist concepts. We can see that they were most likely intended to be and employed as language and religious teaching texts and, if so, give us a rare glimpse into the world of pre-modern Theravāda education in Southeast Asia.

The method of translation and commentary found in nissayas is also similar to that used in Pāli textbooks at the major monastic schools in Thailand. A survey of the published Pāli textbooks popular in Thai monastic schools shows that no matter the level of the text (beginning with Madhyom seuksā p $\vec{i}$ thi neung (approximately 7 th grade in the American sytem or 12-13 years old) up until Madhyom seuksā pị thị hok (12th grade) Pāli grammar is taught by a series of Pāli words displaying a certain grammatical suffix or a type of compound followed by its translation in modern Thai. There is rarely any explanation and textbook that consists of repetitive drills where students must translate single words or short clauses from Pāli into Thai. As the student advances the passages to translate gets slightly longer and what little introduction and explanation there was completely disappears. Moreover, what is interesting is that the lessons are drawn randomly from both canonical and non-canonical texts, and the most popular selections seem to be from paritta prayers that would be familiar to novices, monks, nuns and lay people from chanting during liturgies. In fact, the most common translations of Pāli texts available in Thai religious book- stores (besides Buddhist comic books with stories drawn from Jätakas) are bi-lingual, word-for-word, translations of Pāli liturgies and parittas. While there are too many examples to list and any number of these texts can be bought easily in any major urban center in Thailand, a few examples would be: Nangsēu rīen klum wijābhrapariwatdham, published by Mahāchulalongkornrāja- withyālai (volumes one through six), 2534 [1991], another six volume series of the same title published by Rongbimsāsanā under the auspices of the Department of Education, Pāli wāiyākkorn (six volumes with additional volumes on selected subjects like verbs and compounds) published by Mahāmakuțarājawithyālai, 2538 [1995], and, under the same title, a series published by Krombhrayāwajirayān-worarot, 2538 [1995]. For bi-lingual translations of liturgies see these same publishers. I was told by two different bookstore owners that the Mahāmakuta editions are the best sellers, but have conducted no independent research. ${ }^{59}$

From the textual evidence we can see that nissayas incorporate many of the features of commentaries, or at least commentaries as they are understood in South and Southeast Asia. However, it would be overly reductive and pre-mature to simply label nissayas commentaries, place them back in the archives and monastic libraries, and forget about them. Nissayas diverge from definitions

\footnotetext{
${ }^{59}$ It is interesting to note that there is also a series of English textbooks for religious students published by Mahāmakuṭa Monastic University which uses a very similar method to teach English words and phrases through examples drawn from Buddhist stories translated into English that asks the students to translate them into Thai.
} 
of commentary offered by Griffiths, J.Z.Smith, Henderson among others. First, commentaries in the Pāli tradition are usually understood as being in the same language as the source text. Still, it would be overly reductive to call them vernacular commentaries. Second, nissayas often diverge widely from their particular source text, often to the point that they seem to be re-writing the source text, inventing entire sections or writing a commentary on a source text that may have never existed as a separate text in Pāli or a vernacular. Third, nissayas often contain internal sub-commentaries on their own commentaries of a source text, and it is occasionally difficult to determine whether the author was attempting to teach the meaning of a passage from a source text or comment on her/his own explanation of the source text. Fourth, the source text, as was most apparent in the Atthakathāmātikā Nissaya, is employed as a platform from which to teach grammar, vocabulary, and concepts almost completely divorced from the semantic meaning or original purpose for which the source text seemed to be composed. In this way, the source text plays the role of a canvas that only serves to provide a space for the author of the nissaya to paint his own picture and to widen our understanding of a commentary. The source text no longer guides the sequence, structure, or subject of the commentary. It could be compared to a tourist who strolls through a Bangkok monastery inspired by its architecture, images, and residents to compose, in no particular order, a long journal entry on all and sundry subjects. Finally, if commentaries, as J.Z. Smith and Laurie Patton emphasize, define a canon, then the nissayas define a canon wholly different from that of the Pāli Tipițaka.
Our stroll through the linguistic and codicological world of nissayas, guided by the work by Collins, Hallisey, Cort, J.Z. Smith, Patton and others, have shown us that there are many ways to define a canon. I have hoped to emphasize the importance of seeing how texts were used in an educational context, so as to reflect upon what could have been the unstandardized and particular curricular "canon" of a certain region and certain time. Between the 16th and 19th centuries in Northern Thailand and Laos there was a concerted effort to translate and comment on Pāli texts, both canonical and non-canonical. This constant referral to and manipulation of Indic textual methods, rhetorical styles, tropes, and themes of the past in order to comment on the present was part of the general commentarial and translation (oral, textual, architectural, and artisitc) culture of Southeast Asia. Nissayas were prevalent types of translations and commentaries that manipulated, obfuscated, and elucidated source texts with inventive method of teaching vocabulary, grammar, and occasionally meanings of a seemingly random collection of Pāli texts. These were texts that not only gave the definitions of Pāli words and phrases, but also taught their readers/audience how to incorporate Pāli terms into Lao or Yuan syntax. The pedagogical methods and physical features of the manuscripts show that these texts were listened to, read, collected, and handled. I surmise that from this evidence we can begin to identify, or at least define, the parameters of the general curricula and pedagogical methods for and of monks, nuns and novices (and devoted lay people) of the region and period. This would help us to develop new ways to define what a canon can be. 


\section{References}

Archaimbault, Charles. Contribution a L'Etude D'Un Cycle de Legendes Lau. Paris: Ecole Francaise D'Extreme-Orient, 1980.

Arunsak Kingmanee, "Suvanna-Jataka on the Bai Sema of Wat Nonsila-atwararam," Muang Boran 22.2 (1996): 138-161.

Bassnett, Susan and Andre Lefevere. Eds. Constructing Cultures:

Essays on Literary

Translation. Philadelphia: Multilingual Matters, 1998.

Bassnett, Susan and Harish Trivedi.

Eds. Post-Colonial

Translation: Theory and

Practice. London: Routledge, 1999.

Baynes, H, "A Collection of Kammavācā's," Journal of the Royal Asiatic Society 26 (1892): 53-75.

Bizot, Francois. La Purete par les mots. Paris: Ecole Francaise d'Extreme-Orient, 1996.

Blackburne, Ann. The Play of the Teaching in the Life of the Sāsana: Sārārthadīpanī in Eighteenth Century Sri Lanka. Ph.D. dissertation. University of Chicago, 1996.

Bōsāenggām Wongtālā. Wannakhati Lao. Wiangchān: Sathāpan kongwā Witayāsāt Sangkhom, 1987

Brown, Marvin. From Ancient Thai to Modern Dialects. Bangkok: White Lotus Press, 1985.

Buddhadatta, A.P. Jinakalamali. London: PTS, 1962.

Carpenter, David, "Bhartrhari and the Veda," in Texts in Context: Traditional Hermeneutics in South Asia. Ed. by Jeffrey
Timm. Albany: SUNY Press, 1992.

Cham Tongkamwan, "Kam An Silajareuk Wat Phra Yeun Jangwat Lampun," Sinlapakorn 1 (1957): 61-69

Cherniack, Susan, "Book of Culture in Sung China," Harvard Journal of Asiatic Studies, vol.54, no.1( 1994).

Childs, Brevard. Introduction to the Old Testament as Scripture. Philadelphia: Fortress Press, 1979.

Clough, B, "The Ritual of the Buddhist Priesthood translated from the original Pali work entitled Karmavākya." Londres: 1834.

Coedes, George, "Documents Sur L'Histoire Politique et Religieuse Du Laos Occidental," BEFEO XXV, nos. 1-2 (1925): 4-8. . Catalogue des manuscrits en Pali, Laotien et Siamois provenant de la Thailande. Edited by Kaare Gronbech. Vol. 2, part 2, Catalogue of Oriental Manuscripts, Xylographs etc. in Danish Collections. Copenhague: Biblioteque Royale de Copenhague, 1966.

Collins, Steven, "On the Very Idea of the Pali Canon," Journal of the Pali Text Society XV (1990): 102-117.

Cort, John, "Svemtambar Murtipujak Jain Scripture in a Performative Context," in Texts in Context: traditional Hermeneutics in South Asia. Ed. by Jeffrey Timm. Albany: SUNY Press, 1992.

Bhākvijā Bhāsā Thai.Pañ̃̄āsajātaka chabub pariwat jāk aksorn 
dham. Chiang Mai: Chiang Mai University, 2521(1978).

Dagenais, John. The Ethics of Reading in Manuscript Culture: Glossing the Libro De Buen Amor. Princeton: Princeton University Press, 1994.

Danks, Joseph and Jennifer Griffin, "Reading and Translation: A Psycholinguistic Perspective," Cognitive Processes in Translation and Interpreting. Ed. by Gregory Shreve and Joseph Danks. Thousand Oaks, CA: Sage Pub., 1997.

Dickson, J.F, "The Upasampadākammavācā," Journal of the Royal Asiatic Society 8 (1874): 53-71.

Ellis, Roger. Ed. The Medieval Translator: The Theory and Practice of Translation in the Middle Ages. London: D.S. Brewer, 1987.

Filliozat, Jacqueline, "Documents useful for the Identification of Pali Manuscripts of Cambodia, Laos and Thailand," Journal of the Pali Text Society XVI (1992): 13-54. , "Catalogue of the Pali Manuscript Collection in Burmese and Siamese Characters kept in the Library of Vijayasundararamaya Asgiriya," Journal of the Pali Text Society XXI (1995): 153-91. "A Survey of the Burmese and Siamese Pali Manuscript Collections in the Wellcome Institute," Journal of the Pali Text Society XIX (1993): 1-41.

Finot, Louis, "Researches sur la littérature laotienne," BEFEO 17, 5 (1917): 1-218.

Fishbane, Michael. The Exegetical Imagination. Cambridge: Harvard Univ. Press, 1998.

Frankfurter, O. "A Handbook of Pāli." Londres: 1883.

Garnier, Francis. Further Travels in Laos and in Yunnan. Bangkok: White Lotus, 1996.

Gething, Thomas, Jimmy Harris, and Pranee Kullavanijaya. Eds. Tai Linguistics: in Honor of Fang-Kuei Li. Bangkok: Chulalongkorn Univ. Press, 1976.

Griffiths, Paul. Religious Reading. New York: Oxford Univ. Press, 1999.

Hallisey Charles, "Tuṇụilovāda: an Allegedly Non-canonical Sutta," Journal of the Pali Text Society XV (1990): 155-195.

, "Nibbānasutta: an allegedly non-Canonial Sutta on Nibbāna as a Great City," Journal of the Pali Text Society (1993):97-130.

Harris, Jimmy and James Chamberlain. Eds. Studies in Tai Linguistics in Honor of William Gedney. Bangkok: Office of State Universities, 1975.

Henderson, John. Scripture, Canon and Commentary: A Comparison of Confucian and Western Exegesis. Princeton: Princeton Univ. Press, 1991.

Hinüber, Oscar von, "Pāli Manuscripts of Canonical Texts from Northern Thailand," Journal of the Siam Society 71 (1983): 75-88. , "The Oldest 
Dated Manuscript of the Milindapanha," Journal of the Pali Text Society, XI (1987): 111-119. , "Die

Sprachgeschichte des Pāli im Spiegel der südostasiatischen Handschriftenuberlieferung," Untersuchungen zur Sprachgeschichte und Handschriftenkunde des Pāli I. Stuggart, 1988. , "An

Additional Note on the Oldest Dated Manuscript of the Milindapanha," Journal of the Pāli Text Society XII (1988): 173-74. , "Chips from Buddhist Workshops: Scribes and Manuscripts from Northern Thailand," Journal of the Pāli Text Society XXII (1996): 35-57. , on Some Colophones of Old Lanna Pali Manuscripts," Proceeding of the $4^{\text {th }}$ International Conference of Thai Studies, Vol. IV. , A Handbook

of Pāli Literature. Berlin: Walter de Gruyter, 1996. Hodges, Ian, "Time in Transition: King Narai and the Luang Prasoet Chronicle of Ayutthaya," Journal of the Siam Society 87, 1\&2 (1999): 33-44.

Hosington, Brenda, "Partonopeu de Blois and its FifteenthCentury English Translation: A Medieval Translator at Work," The Medieval Translator. Ed. by Roger Ellis. London: Centre for Medieval Studies, University of
London, 1991: 231-52.

Hundius, Harold, "Colophons from thirty Pāli Manuscripts from Northern Thailand," Journal of the Pali Text Society XIV (1990): 1-179. , Phonologie und Scrift des Nordthai. Abhandlungen für die Kunde des Morprgenlandes. Stuttgart: Franz Steiner,1990. Jaini, Padmanabh. Ed. Pañ̃̄āsajātaka or Zimme Pannāsa, Vols.I \& II. London: Pāli Text Society, 1983. , "The Apocryphal Jātakas of Southeast Asian Buddhism," Indian Journal of Buddhist Studies I, part 1 (1989): 22-37.

Jakobson, Roman, "On Linguistic Aspects of Translation." Brower, Reuben. Ed. On Translation. Cambridge: Harvard Univ. Press, 1959: 232-40.

Jayaywickrama, N.A. Trans. The Sheaf of Garlands of the Epochs of the Conquerer. London: PTS, 1968.

Kānthām Samutthai lae Kāntrīem Bāilān. Bangkok: Hōsamut hāeng chāt, 2530 [1988].

Katannyu Chucheun. Aksornboran ti chai bantuek wanakamm thai. Bangkok: Ganakammkan wichai haeng chat, 1987.

Khongdeuan Bunyāwong. Ed. Thao Hung Thao Cheung [based on Mahāsilla Wirawong's 1942 prose translation]. Vientiene: Toyota Foundation Edition, 2000.

LaFont, Pierre Bernard, "Inventaire des manuscripts des pagodes du Laos," BEFEO 52 (1965): 429-545. 
Lancaster, Lewis. "An Analysis of the Astasahāśrikaprajūā pāramitāsūtra from the ChineseTranslations." Ph.D. dissertation, University of Wisconsin, 1968.

Luce, G.H. and Tin Htway, "A 15th Century Inscription and Library at Pagan, Burma," Maslasekara Commemoration Volume. Ed. by O.H. de A.Wijesekara. Columbo: Malasekara Commemoration Volume Editorial Committee, 1976.

McDaniel, Justin, "Creative Engagement: the Sujavanna Wua Luang and its Contribution to Buddhist Literature,"Journal of the Siam Society 88.1 \& 2(2000): 156-177. , "Transformative History: Nihon Ryōki and Jinakālamātipakaranam," Journal of the International Association of Buddhist Studies (forthcoming).

Merrill, James. Into the American Woods: Negotiators on the Pennsylvania Frontier. New York: Norton \& Co., 2000.

Mookerji, Radha Kumud. Ancient Indian Education:

Brahmanical and Buddhist. Delhi: Motilal Banarsidass, 1947.

Charlotte Morse et al. The Uses of Manuscripts in Literary Studies. Kalamazoo, MI: Medieval Institute Publications, 1992.

Nabokov, Vladimir, "The Servile Path," On Translation. Ed. by Reuben Brower. Cambridge: Harvard Univ. Press, 1959:
97-111.

Natwipha Chalitanon. Prawatisat Nipon Thai. Bangkok: Thammasat University Press, 1984.

Niyada Lausunthorn. Pañ̃̃āsajātaka: prawat lae kwām sāmgān $\overline{t i} m \bar{l}$ to wanakam roi krong khong Thai. Bangkok: Mae Gām Phāng Pub., 1997.

Notton, Camille. Trans. Annales $d u$ Siam, Vol. II. Paris, 1930.

Norman, K.R., "Pāli Literature," A History of Indian Literature, vol. 7, pt. 2. Ed. by Jan Gonda. Wiesbaden: Otto Harrassowitz, 1983.

O'Keefe, Katherine, "Editing and the Material Text," The Editing of Old English: Papers from the 1990 Manchester Conference. Ed. by D.G. Scragg and Paul Szarmach. New York: D.S. Brewer, 1991: 148-151.

Pāeprīe nangsēu bhāsāporān. Bangkok: Hōsamut hāeng chāt,2543[1999].

Panchi Maigrofilm Kwang L L'̈'ang Pabāng, Hō Papitapan Kwang Lü'ang Pabāng, Hongsamut Haeng Chāt Lao (Catalogues of Palm Leaf Texts on Microfilm from Luang Pabang, the Museum of Luang Pabang and from the National Library of Laos). Vientiene:

Kronggānpotpakhaksā Neungseu pailān Lao, 1999.

Pannasami. The History of the Buddha's Religion. Trans. By B.C. Law. London: PTS, 1952.

Patton, Laurie. Myth as Argument:

The Brhaddevatā as Canonical Commentary. Berlin: De Gruyter Press, 1996. 
Penth, Hans, "Buddhist Literature of Lan $\mathrm{Na}$ on the History of Lan Na's Buddhism," Journal of the Pāli Text Society XXIII (1997): 43-81.

Peters, Anne, "Die birmanischen

Kammavācā-Sammlungen mit nem Abschnitten,"

Untersuchungen zur

buddhistischen Literatur II.

Ed. by Heinz Bechert, Sven

Bretfeld and Petra Kieffer-

Pulz. Gottingen: Vandenhoeck and Ruprecht, 1997: 275-283.

Pope, Marvin, trans. and commentary, The Anchor Bible: Song of Songs. Garden City, New York: Doubleday \& Co., 1977.

Phra kawïwarañān, "Phra

Dhammadesanā

Piyakaranakathā," Phra

Dhammadesanā Song Phra

Karuna Brot Klao.

Bangkok,2528[1985].

Phra Khrū Runathamarangssi' Monpīiti

blae samrap

Phrabhiksusāmanen lāe

Phutthasāsanikachon tua bai

(Bangkok: Wat

Arunarārāchawarārām,2534

[1991].

Phra Priyatthïrakhun, "Phra

Dhammadesanā

Dhammacārikkathā," Phra

Dhammadesanā Song Phra

Karuna Brot Klao. Bangkok, 2528 [1985].

Pratt, Karen, "Medieval Attitudes on

Translation and Adaption: the

Phetorical Theory and the

Poetic Practice," The

Medieval Translator. Ed. by

Roger Ellis. London: Centre

for Medieval Studies,

University of London, 1991:

1-27.
Prawetsanthonhom. Vientiane: Sūn gān kon kwā, 1993.

Pruitt, William, "Un Nissaya Birman de la Bibliotheque Nationale, le Patimikkha. Étude linguistique: premiere partie, Cahiers de l'Asie du Sud-Est 19 (1986): 84-119. "Un Nissaya Birman de la Bibliotheque Nationale, le Patimikkha. Etude linguistique: deuxieme partie, Cahiers de l'Asie du Sud-Est 21 (1987): 7-45. , "'Un Nissaya Birman de la Bibliotheque Natiojnale, le Patimikkha. Étude linguistique: troisieme partie, Cahiers de l'Asie du Sud-Est 22 (1987): 35-57. Etude linguistique de nissaya Birmans: traduction commentée de Textes Bouddhiques. Paris: Ecole francaise d'extreme-orient, 1994.

Raichü' nangs $\bar{u}^{\prime}$ porān lānnā ekasān maigrofilm kong satāpan wijai chiangmai: $2521-2533$

(Catalogue of Palm Leaf Texts on Microfilm at the Social Research Institute, Chiang Mai University: 1978-1990). Chiang Mai: SRI, 1991.

Robinson, Fred. The Editing of old English.Oxford; Blackwell Press, 1982: chapter one. , "Pāli Literature from Laos," Narain, A.K. and L. Zwilling. Eds., Studies in Pāli and Buddhism. Delhi: B.R. Pub., 1979.

Sanguan Chotsukrat. Tamnan Muang Nua. Krung Thep: Odiansdon, 1965. . Prachum Tamnan Lanna Thai, Vols. $1 \& 2$. 
Krung Thep: Odiansadon, 1972.

Prasert na Nagara. $T$

Chiang Mai Chiang Tung.

Krung Thep: Ekasanwichagan

Samakhom Phrawattisat, 1994.

Sap Phrakopsuk, Wanakhadichādok

Bangkok: Wat Porohit, 1984

Satien Goset, "Wicha Brawattisat."

Silapakorn 1, no. 3 (1957):

70-74.

Prince Savang Phouvong, et al., sous

la direction d' Henri Deydier,

"Un Fragment Inconnu du

Paññāsajātaka Laotien," ed.

by Jacqueline Filliozat and

Anatole Peltier. Chiang Mai-

Paris-Vientiane: Ecole

francaise d'Extreme-orient, 1995-97.

Schweisguth, P. Etude Sur La

Litterature Siamoise. Paris:

Imprimerie Nationale, 1951: 43-44.

Shore, Lys Ann, "The Continuum of

Translation as Seen in Three

Middle French Treatises on

Comets," Translation and the

Transmission of Culture

between 1300-1600. Ed. by

Jennette Beer and Kenneth

Lloyd-Jones. Kalamazoo,

Michigan: Studies in

Medieval Culture, Western

Michigan Univ., 1995: 1-31.

Schuyler, M, "Notes on the making of

Palm-Leaf Manuscripts in

Siam," Journal of the

American Oriental Society, 29

(1908): 281-83

Skilling, Peter, "The Raksa Literature of Sravakayana," Journal of the Pāli Text Society XVI (1992): 109-82.

Smith, Jonathan Z. Map is not

Territory. Leiden, 1978.
Imagining

Religion: From Babylon to

Jonestown. Chicago: Univ. of

Chicago Press, 1982.

Sommai Premcit. "Palm Leaf

Manuscripts and Traditional

Sermon." Buddhism in

Northern Thailand. Ed. by

Saeng Chandranngaam.

Chiang Mai: Proceedings of the 13th Conference of the

World Fellowship of

Buddhists, 1980.

Speigel, F. "Kammavākya: Liber

Officis sacerdotum buddhicorum, palice et latine primus edidit atque adnotationes adjecit." Bonn: 1841.

Stock, Brian. The Implications of Literacy: Written Language and Models of Interpretation in the Eleventh and Twefth Centuries. Princeton University Press, 1983.

Stuart-Fox, Martin. The Lao Kingdom of Lan Xang: Rise and Decline. Bangkok: White Lotus, 1998.

Suatmon chabab lü'ang blāe ( Royal Chanting Book Text and

Traslation), 12th edition

Bangkok:

Mahāmakutrāchawithayalai: 2518[1975].

Suatmon chabab lü'ang (Royal

Chanting Book Text and

Traslation), 12th edition

Bangkok:

Mahamakutrachawithayalai:

2518[1975].

Suatmon Mü'ang Nü'a chabab

sombūn, Chiang Mai:

Dhārāthong Kānbim, 2537

[1994].

Suchita Wongtet. "Kamnamsaneur."

Mahagap Kong Usakanae Tao 
Hung Kun Cheung

Wirburussongfangkong. Ed. by Suchita Wongtet. Bangkok: Singhakom, 1985.

Swearer, Donald and Sommai

Premchit, "A Translation of

Tamnan Mulasasana Wat Pa

Daeng: The Chronicle of the founding of Buddhism of the Wat Pa Daeng Tradition." Journal of the Siam Society 65, part II (1977).

"The Relationship between the Religious and Political Orders in Northern Thailand (14th to 16th centuries)." Religion and Legitimation of Power in Thailand, Laos and Burma. Ed. Bardwell Smith. Chambersburg, PA: Anima Books, 1978.

The Legend of Queen Cama: Bodhiramsi's Camadevivamsa a Translation and Commentary. Albany: SUNY, 1998.

Sweller, J. and Cooper, G.A., "The Use of Worked Examples as a Substitute for Problem Solving in Learning Algebra," Cognition and Instruction 2 (1985): 59-89.

Tanselle G. Thomas, " The varieties of Scholarly Editing," in Scholarly Editing: A Guide to Research. ed. by D.C. Greetham. New York: The Modern Language Association of America, 1995. Timm, Jeffrey. Ed. Texts in Context: Traditional Hermeneutics in South Asia. Albany: SUNY Press, 1992.

Tin Tun. ed. The Royal Orders of Burma. Vol. I.Kyoto: Center for Southeast Asian Studies, Kyoto Univ., 1983.

Viravongsa, Mahasila. Wannakhadi Lao. Wiangchān: Mahasila Viravongsa, 1995.

Wade, Geoffrey, "The Ming shi-lu as a Source for Thai History: Fourteenth to Seventeenth Centuries," Journal of Southeast Asian Studies 31, 2 (2000): 249-294.

Richard White. Middleground: Indians, Empires and Republics in the Great Lakes Region (1650-1815). Cambridge: Cambridge Univ. Press, 1991.

Wichienkeeo, Arronrut and David Wyatt. The Chiang Mai Chronicle. Chiang Mai: Silkworm Books, 1998.

Wollin, Lars, "The Monastery of Vadstena: Investigating the Great Translation Workshop in Medieval Scandinavia," The Medieval Translator, ed. by Roger Ellis. London: Centre for Medieval Studies, University of London, 1991.

Worth-Stylianou, Valerie, "Reading Monolingual and Bilingual Editions of Translations in Renaissance France, " Translation and the Transmission of Culture between 1300-1600. Ed. by Jennette Beer and Kenneth Lloyd-Jones. Kalamazoo, Michigan: Studies in Medieval Culture, Western Michigan Univ., 1995: 331-58.

Wray, Elizabeth Clare Rosenfield and Dorothy Baily's Ten Lives of the Buddha: Siamese Temple Painting and Jātaka Tales. New York: Weatherhill, 1972. 